\title{
Slab break-offs in the Alpine subduction zone
}

\author{
Emanuel D. Kästle ${ }^{1}$ (1) $\cdot$ Claudio Rosenberg ${ }^{2} \cdot$ Lapo Boschi $^{3} \cdot$ Nicolas Bellahsen $^{2} \cdot$ Thomas Meier $^{4} \cdot$ Amr El-Sharkawy $^{4,5}$
}

Received: 12 December 2019 / Accepted: 8 January 2020

(c) The Author(s) 2020

\begin{abstract}
After the onset of plate collision in the Alps, at 32-34 Ma, the deep structure of the orogen is inferred to have changed dramatically: European plate break-offs in various places of the Alpine arc, as well as a possible reversal of subduction polarity in the eastern Alps have been proposed. We review different high-resolution tomographic studies of the upper mantle and combine shear- and body-wave models to assess the most reliable geometries of the slabs. Several hypotheses for the tectonic evolution are presented and tested against the tomographic model interpretations and constraints from geologic and geodetic observations. We favor the interpretation of a recent European slab break-off under the western Alps. In the eastern Alps, we review three published scenarios for the subduction structure and propose a fourth one to reconcile the results from tomography and geology. We suggest that the fast slab anomalies are mainly due to European subduction; Adriatic subduction plays no or only a minor role along the Tauern window sections, possibly increasing towards the Dinarides. The apparent northward dip of the slab under the eastern Alps may be caused by imaging a combination of Adriatic slab, from the Dinaric subduction system, and a deeper lying European one, as well as by an overturned, retreating European slab.
\end{abstract}

Keywords Seismic tomography $\cdot$ Subduction slabs $\cdot$ Alpine subduction system $\cdot$ Slab break-off $\cdot$ Slab polarity reversal

\section{Introduction}

The Alps and the adjacent Apennine, Dinaric and Carpathian mountain chains (Fig. 1) were formed by a complex history of subduction, collisions and backarc extension. During $\mathrm{N}-\mathrm{S}$ convergence of Africa and Europe (e.g., Dewey et al. 1989; Stampfli and Borel 2002), between 84 Ma and $35 \mathrm{Ma}$, Adria-Africa acted as upper plate along most of the subduction front while the Alpine Tethys (in addition

Electronic supplementary material The online version of this article (https://doi.org/10.1007/s00531-020-01821-z) contains supplementary material, which is available to authorized users.

Emanuel D. Kästle

emanuel.kaestle@fu-berlin.de

1 Institute of Geological Sciences, Freie Universität Berlin, Malteserstr, 74-100, 12249 Berlin, Germany

2 Institut Des Sciences de la Terre, Paris (iSTeP), Sorbonne Université, Paris, France

3 Dipartimento di Geoscienze, Università degli Studi di Padova, Padua, Italy

4 Christian Albrechts Universität, Kiel, Germany

5 National Research Institute of Astronomy and Geophysics (NRIAG), Helwan, 11421 Cairo, Egypt to the distal European margin) was subducted towards the south (e.g., Schmid et al. 2004; Handy et al. 2010). During this time, an opposite subduction direction affected what would become the Dinaric-Hellenic arc (Laubscher 1971; Pamić et al. 2000; Schmid et al. 2008; Ustaszewski et al. 2008; Fig. 2) and possibly also the southern Apennines (Molli and Malavieille 2011; Argnani 2012). During the transition between subduction and collision (50-35 Ma, e.g., Handy et al. 2010; Carminati et al. 2012), slab breakoffs are inferred to have occurred in different parts of the Alpine collision zone (e.g., Blanckenburg and Davies 1995; Lippitsch et al. 2003; Harangi et al. 2006; Kissling et al. 2006), partly preceding reversals of subduction polarity, as in the northern Apenninic collision (Vignaroli et al. 2008; Handy et al. 2010; Molli and Malavieille 2011) and possibly in the eastern Alps (Schmid et al. 2004; Handy et al. 2015). In this area, tomography results (Lippitsch et al. 2003) triggered a discussion on the apparent northward dip of the slab between 50 and $250 \mathrm{~km}$ depth, suggesting that it may result from subduction of Adria under Europe (Schmid et al. 2004; Ustaszewski et al. 2008; Schmid et al. 2013; Handy et al. 2015), hence from a change in subduction polarity, starting at around $20 \mathrm{Ma}$. This change would have been possible after one or possibly two proposed break-off events of the 


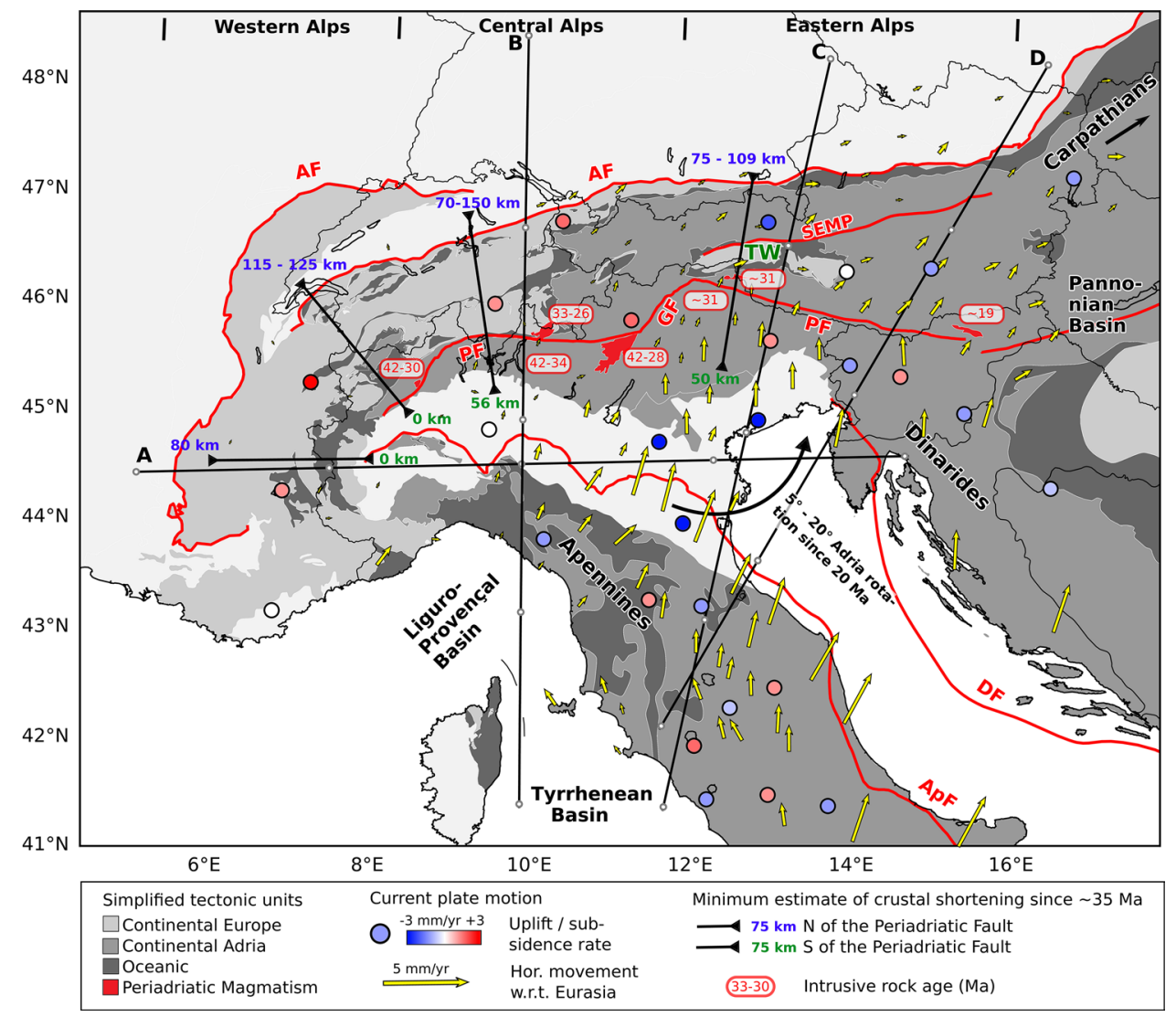

Fig. 1 Map of the tectonic units, plutonic ages, shortening estimates as well as past and present surface motions. The cross-sections labeled A-D are shown in Figs. 3 and 4, section D is chosen to mimic section $\mathbf{c}$ in Lippitsch et al. (2003). Tectonic units and major lineaments simplified from Schmid et al. (2004, 2008); Handy et al. (2010); ages of Periadriatic magmatism: Del Moro et al. (1983); Barth et al. (1989); Bigioggero and Colombo (1994); Romer et al. (1996); Müller et al. (2000); Oberli et al. (2004); Fodor et al. (2008); Berger et al. (2012); Bergomi et al. (2015); Ji et al. (2019); shorten- ing estimates: Schmid et al. (1996); Frisch et al. (1998); Schönborn (1999); Nussbaum (2000); Schmid et al. (2004); Bellahsen et al. (2014); Rosenberg et al. (2015); Schmid et al. (2017); Rosenberg et al. (2019); rotation of Adria: Ustaszewski et al. (2008); Le Breton et al. (2017); GPS horizontal: Metois et al. (2015); GPS vertical: Serpelloni et al. (2013). AF Alpine Front, $A p F$ Apenninic Front, $D F$ Dinaric Front, $P F$ Periadriatic Fault, $G F$ Giudicarie Fault, SEMP Salzach-Ennstal-Mariazell-Puchberg fault, $T W$ Tauern Window

structure differently and are better suited to resolve the crust-mantle transition zone (Kästle et al. 2018). To assess the most reliable geometry of the slabs based on presentday tomographic models, we review the upper structure of the slabs with models derived from both methods. The results are illustrated by four orogen-perpendicular crosssections (Fig. 1) that allow one to systematically compare the different tomographic models. Such a detailed side-by-side comparison cannot currently be found in the literature, yet it is a necessary step to establish what we really know about the mantle structure under the Alpine belt. The tomographic findings are integrated in the geodynamic context of Alpine collision, for which we describe the amounts of shortening, the ages of syn-collisional magmatism, present-day plate motions as well as past and present uplift (Fig. 1), to investigate whether slab breakoffs took place and how they affected the Alpine orogen. 

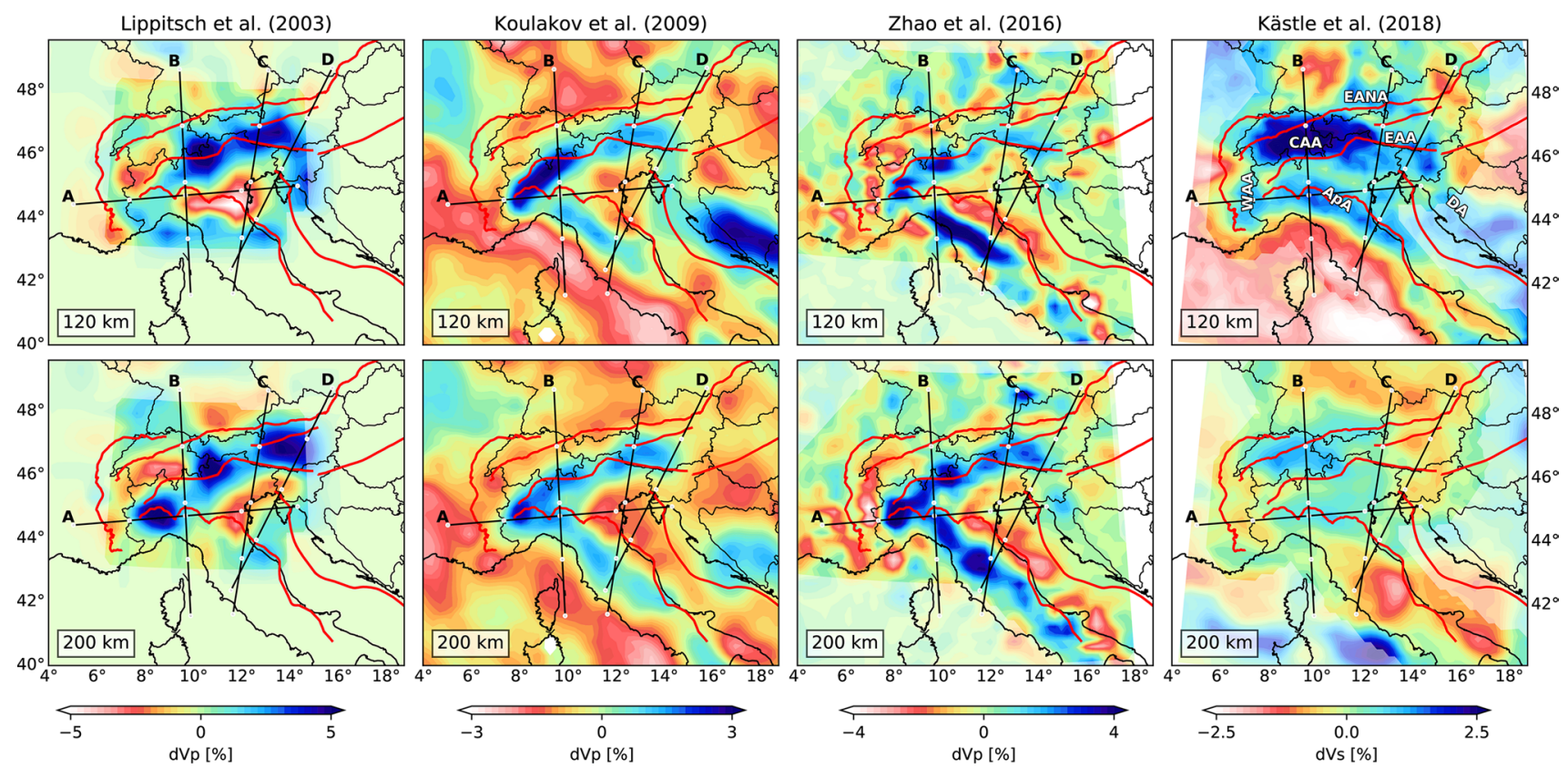

Fig. 2 Uppermost mantle structures according to different studies shown as velocity deviations from a regional average at $120 \mathrm{~km}$ and $200 \mathrm{~km}$ depth. Kästle et al. (2018): shear velocity deviations, other models: compressional velocity deviations. The cross-sections labeled A-D are shown in Figs. 3 and 4. First-order faults (red lines) simplified from Schmid et al. (2004, 2008); Handy et al. (2010).

\section{Tomographic imaging}

While including information from different disciplines, the focus of this work lies in comparing and interpreting tomographic images derived from different studies. However, the comparability of models obtained with different methods and different datasets is not straightforward. We show several models based on body waves (Piromallo and Morelli 2003; Lippitsch et al. 2003; Koulakov et al. 2009; Dando et al. 2011; Mitterbauer et al. 2011; Zhao et al. 2016a; Hua et al. 2017), a recent one based on surface waves (Kästle et al. 2018) and two more based on full-waveform inversion, i.e., using both body and surface waves, in the supplementary material (Zhu et al. 2015; Fichtner et al. 2018). The imbalance between the number of surface- and body-wave models in this comparison is explained by the fact that it has only been possible after the recent densification of seismic arrays to use surface waves to image the relatively 'smallscale' slab geometries underneath the Alps. The difficulty in comparing models lies, however, not only in using different wave types but also in differences in datasets (number and geometry of station networks), data corrections (e.g., correcting for crustal structure or elevation), data preparation (e.g., filtering, picking of P-/S-phases), data quality (strict or loose rejection of noisy data) as well as technical choices of the researchers such as model regularization

Highlighted fast anomalies: WAA Western Alpine Anomaly, $C A A$ Central Alpine Anomaly, EAA Eastern Alpine Anomaly, EANA Eastern Alpine Northern Anomaly, ApA Apenninic Anomaly, DA Dinaric Anomaly. Reduced color intensities indicate low-resolution regions of the models as defined in the original works

(damping and smoothing), parameterization (grid spacing/ cell size) or the underlying physical model (e.g., wave propagation as straight rays, bent rays or sensitivity kernels). All of these will finally influence the resolution of a model and consequently it is not possible to absolutely quantify the uncertainties for each of the models. For example, the imaged amplitudes of the velocity variations in the subsurface vary significantly between different models although the underlying dataset may be quite similar (e.g., Piromallo and Morelli 2003; Koulakov et al. 2009), for this reason we use the same color map for the analyzed models in the present study, but with different color-scale limits for each model. To provide the reader with the first-order differences between the models, we summarize their key parameters in Table 1; for a more detailed discussion of the models and an estimate of their resolution, the reader is referred to the original publications.

\section{Surface-wave tomography}

Surface-wave phase velocities are particularly sensitive to the vertical changes in shear-wave velocities, therefore they are well suited for probing the lithosphere and the asthenosphere. In several studies, surface waves measured from ambient noise signals have been successfully used to obtain detailed images of the crustal structure under the Alps (Yang 
Table 1 Comparison of the key parameters for the models discussed in the text and shown in Figs. 2, 3, S1-S14. The abbreviations $t$ and $r$ stand for teleseismic and regional

\begin{tabular}{|c|c|c|c|c|c|c|}
\hline & \# stations & \# earthquakes & \# measurements & Hor. grid & Crustal corrections & Coverage \\
\hline $\begin{array}{l}\text { Piromallo and Morelli } \\
\text { (2003) }\end{array}$ & $>300$ & $\sim 52,000$ & $\begin{array}{l}52,514(r) \\
59,625(t)\end{array}$ & $0.5^{\circ}$ & $\begin{array}{l}\text { No correction but regional } \\
\text { events }\end{array}$ & Entire Europe \\
\hline Lippitsch et al. (2003) & $\sim 200$ & 76 & $4,199(t)$ & $50 \mathrm{~km}$ & $\begin{array}{l}\text { Different local models, own } \\
\text { compilation }\end{array}$ & Alps \\
\hline Koulakov et al. (2009) & $\sim 200$ & $>1000$ & $>40,000(\mathrm{r} \& \mathrm{t})$ & Variable $(>30 \mathrm{~km})$ & EuCRUST-07 & Entire Europe \\
\hline Dando et al. (2011) & 100 & 225 & $23,869(t)$ & $25 \mathrm{~km}$ & $\begin{array}{l}\text { Different local models, own } \\
\text { compilation }\end{array}$ & Parts of the Alps \\
\hline Mitterbauer et al. (2011) & 154 & 80 & $6,369(t)$ & $30 \mathrm{~km}$ & $\begin{array}{l}\text { Different local models, own } \\
\text { compilation }\end{array}$ & Parts of the Alps \\
\hline Zhu et al. (2015) & 745 & 190 & - & $\sim 40 \mathrm{~km}$ & Does not apply & Entire Europe \\
\hline Zhao et al. (2016a) & 527 & 199 & $41,838(t)$ & $25 \mathrm{~km}$ & EPCrust & Alps \\
\hline Hua et al. (2017) & 667 & $\begin{array}{l}12,644(t) \\
4014(r)\end{array}$ & $\begin{array}{l}493,386(t) \\
117,885(r)\end{array}$ & $0.5^{\circ}$ & $\begin{array}{l}\text { Does not apply; Moho depth } \\
\text { fixed from EuCRUST-07 }\end{array}$ & Alps \\
\hline Kästle et al. (2018) & 511 & Does not apply & $\sim 90,000$ & $10 \mathrm{~km}$ & Does not apply & Alps \\
\hline Fichtner et al. (2018) & - & 52 & $>13,089(\mathrm{r} \& \mathrm{t})$ & Variable $(>30 \mathrm{~km})$ & Does not apply & Global \\
\hline
\end{tabular}

Note that the parameter values are not a measure for the resolution or quality of the models. Resolution depends additionally on the data quality, geometry of the data coverage and quality of the corrections. A dash means that no information was available. In some cases, the crust is part of the model, so that a crustal correction does not apply. The model of Fichtner et al. (2018) is constantly evolving by incorporating new models, the values are therefore taken from Fichtner and Villaseñor (2015). EPCrust: Molinari and Morelli (2011); EuCRUST-07: Tesauro et al. (2008); the reader is referred to the original publications for the references to the local models used in the own crustal model compilations

et al. 2007; Stehly et al. 2009; Fry et al. 2010; Verbeke et al. 2012; Molinari et al. 2015), and more recently, thanks to the densification of the seismic station arrays, also to image both crust and uppermost mantle (Kästle et al. 2018; Lu et al. 2018). Deeper structures can be imaged by measurements of earthquake-generated surface waves but they are limited in resolution so that individual slabs under the Alpine arc can often not be distinguished (e.g., Boschi et al. 2004; Schivardi and Morelli 2009; Auer et al. 2014; Soomro et al. 2016; Nita et al. 2016). An exception is the study by Lyu et al. (2017) who take advantage of the very dense CIFALPS transect in the western Alps (Zhao et al. 2016b) and derive a detailed crustal and upper mantle structure along the profile from teleseismic surface waves. For the model comparison in this study, we only take our recently published model (Kästle et al. 2018) into account (Figs. 2, 3), because it makes use of a combination of ambient noise and earthquake-based measurements and rigorously discusses the uppermost mantle structures of the entire Alpine area. This approach resulted in a broad frequency range (4-300 s) of measurements, and an unprecedentedly dense ray-path coverage of the region. From the inversion of the phase-velocity measurements, we constructed a high-resolution 3D shear-wave velocity model underneath the Alpine region, showing that a 100-km-thick anomaly (as from a lithospheric slab) can be identified down to $200 \mathrm{~km}$ depth (Figs. 2, 3).

The positions of the anomalies are subject to increasing uncertainty with depth, meaning that the surface-wave model is not well suited to estimate the slab dip. This may cause some differences in the anomaly positions with respect to the body-wave models. Tests have shown that the size of the anomaly should not be smaller than $\sim 25 \%$ of the wavelength to be resolvable (Bodin and Maupin 2008). Surface waves that are most sensitive to structures at $100 \mathrm{~km}$ depth have a period of around $60 \mathrm{~s}$ (Smith et al. 2004) and an average wavelength of $270 \mathrm{~km}$ (at $200 \mathrm{~km}$ depth, the period becomes $150 \mathrm{~s}$ and the wavelength $675 \mathrm{~km}$ ). This means, at the bottom of the model domain at $200 \mathrm{~km}$ a slab anomaly can easily be misplaced by $150 \mathrm{~km}$. Smearing and weakening of the imaged anomalies are not only caused by the large wavelengths but also by the reduction in data coverage at long periods in the dataset (Kästle et al. 2018). Complexities in the propagation path of surface waves can also affect the uncertainty in the deeper part of the model where it is largely constrained by earthquake data (Kolínsky et al. 2019). Given that we use a pre-AlpArray (Hetényi et al. 2018a) dataset, there is a considerable variability in station coverage which can additionally cause lateral variations in anomaly strength. Areas with sparse station coverage tend to show reduced anomaly strengths and vice versa. This may enhance the anomaly, for example, in Switzerland (Fig. 2), where the station coverage is denser. To ensure that these uncertainties do not affect our interpretation, we evaluated and tested two independent datasets (from ambient noise and from earthquake data) before merging them into the model shown in Figs. 2 and 3 (Kästle et al. 2016, 2018). Resolution tests that show how the station coverage affects the recovered anomalies are shown in Kästle et al. (2018). 


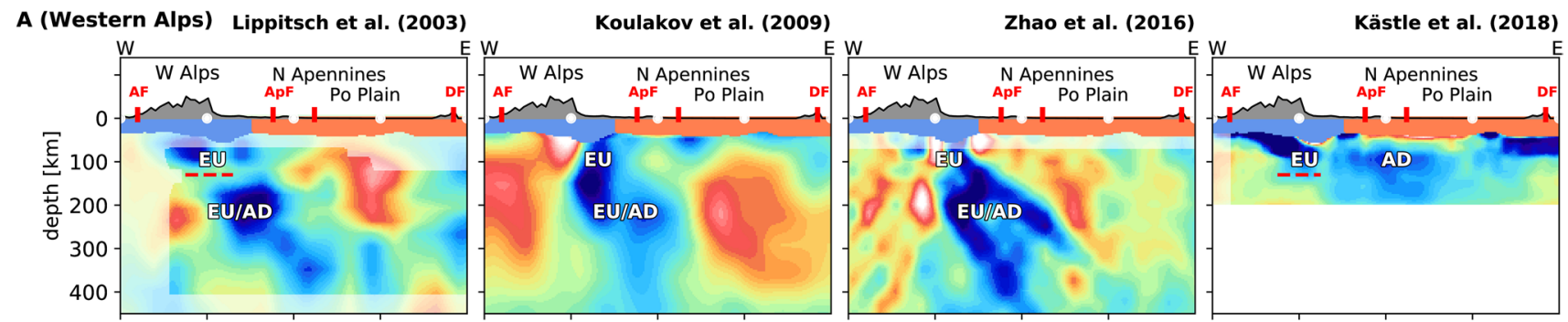

B (Central Alps)
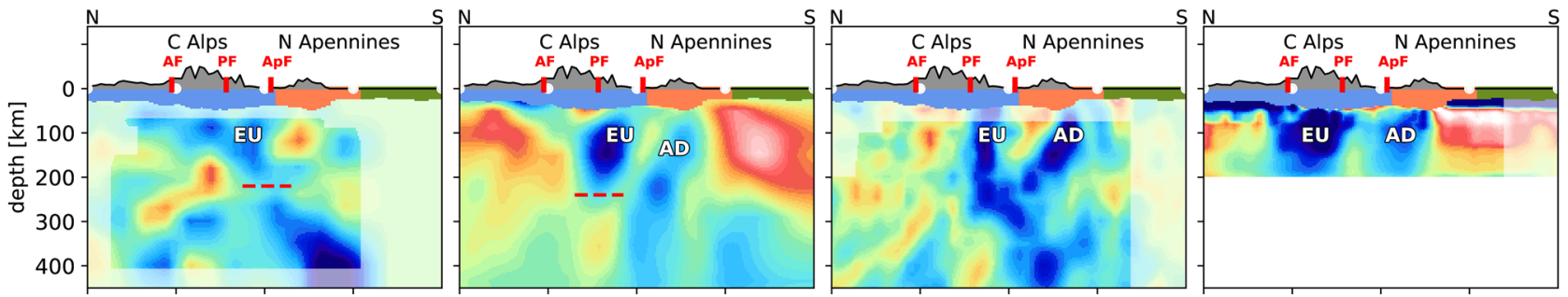

\section{C (Eastern Alps)}
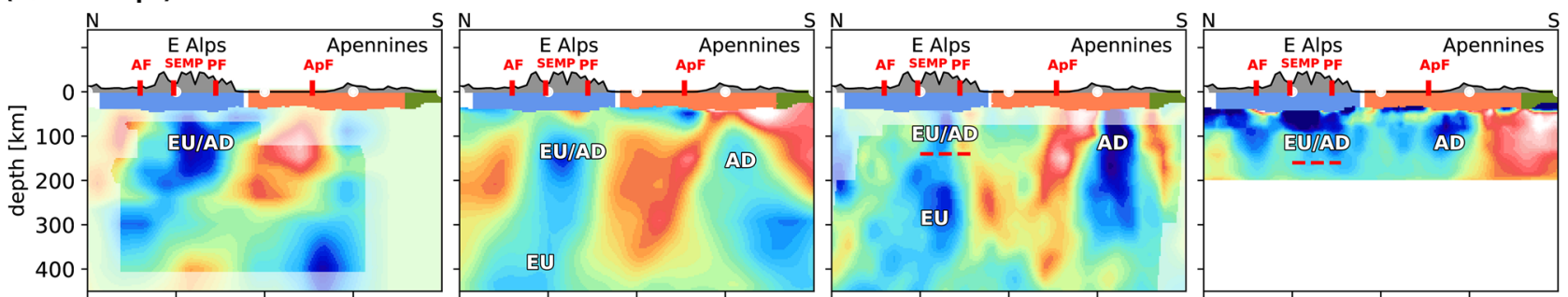

D (Eastern Alps)
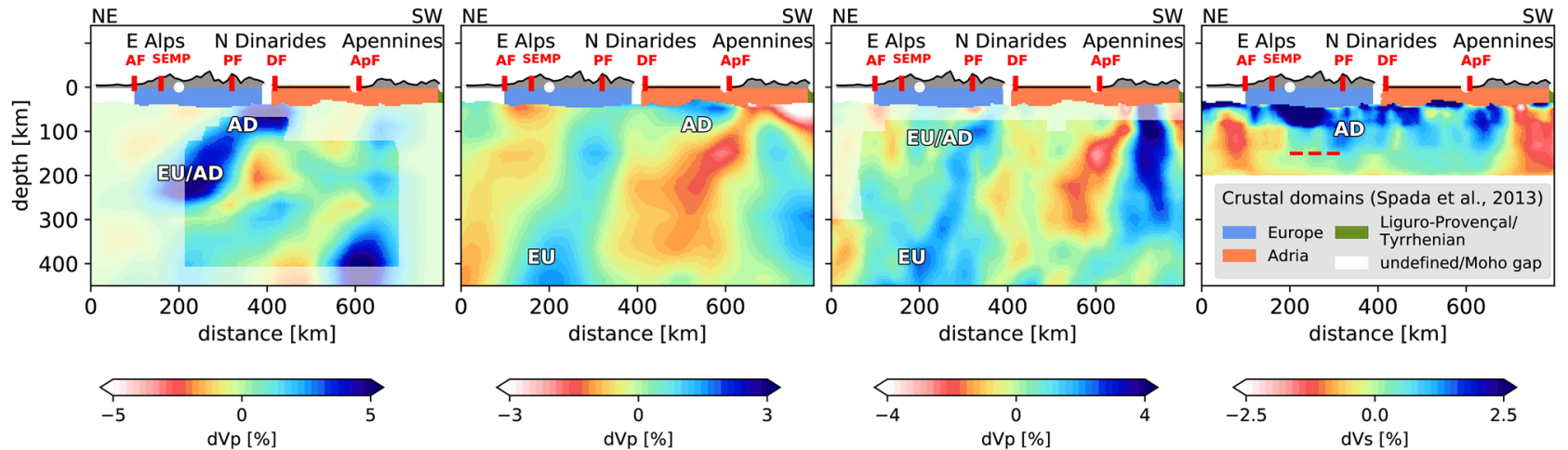

Fig. 3 Cross-sections through four tomographic models along crosssections a-d (see Fig. 2). The models of Lippitsch et al. (2003), Koulakov et al. (2009) and Zhao et al. (2016a) are based on body waves, while the one of Kästle et al. (2018) is based on surface waves. The models show velocity anomalies with respect to a regional average. The absolute anomaly strengths may vary between models due to the chosen color scale, model parameterization, model uncertainties and

The clearest velocity anomaly is obtained from the thick European slab under the central Alps (Figs. 2, 3). The Adriatic slab underneath Apennines and Dinarides is associated with a weaker high-velocity anomaly, which may be due to a thinner slab, or to a lower resolution, because the station distribution is not homogeneous, i.e., very linear within Italy and very sparse along the Dinarides. inversion methods (see text). The abbreviations in the cross-sections indicate our reinterpretations of the provenance of the slab anomalies, either European (EU), Adriatic (AD) or unclear/both (EU/AD). The dashed lines indicate the different discussed levels of slab break-off. Reduced color intensities indicate low-resolution regions of the models as defined in the original works. Red annotations at the surface correspond to major lineaments shown in Fig. 1

In the following, we describe the structure and orientation of the Alpine high-velocity anomalies based on the surfacewave model.

Central Alps The strongest and most continuous highvelocity anomaly is found under the central Alps. It extends from the bottom of the crust down to the lower boundary of the mapped region at $200 \mathrm{~km}$ depth, suggesting a continuous 
slab of at least $100 \mathrm{~km}$ length (Fig. 3b). The anomaly extends in $\mathrm{E}-\mathrm{W}$ direction from 7 to around $12.5^{\circ}$, with a thickness of up to $100 \mathrm{~km}$. From the surface-wave data, no break-off can be inferred for the imaged depth range.

Western Alps In contrast to the central Alps, there is no clear, continuous high-velocity anomaly under the western Alps in our shear velocity model (Fig. 3a). The fast, lithospheric velocity anomaly under the western Alps (European) vanishes at depths below $90-120 \mathrm{~km}$. We interpret the broader, fast anomaly under the northern Apennines as Apenninic slab whose shape along strike is illustrated by the cross-section in Fig. 3a (compare Fig. 2). There is no continuity between the shallow western Alpine (European) and the Apenninic (Adriatic) fast anomalies (Fig. 3a). From the contrast to the central Alpine structure and the missing vertical continuation to depths greater than $150 \mathrm{~km}$, we conclude that the European slab underneath the western Alps is not as thick and continuous as under the central Alps and may have broken off. The geometry of the proposed breakoff cannot, however, be resolved with surface waves alone. The reduction of shear velocities is observed underneath the entire western Alpine area in Fig. 2 and is still within a 50\% wavelength threshold. The imaged geometries in the surfacewave model of Lyu et al. (2017) along the CIFALPS transect suggest rather a continuous slab below the western Alps.

Eastern Alps The central Alpine anomaly extends eastward to $12-13^{\circ} \mathrm{E}$, coinciding approximately with the Giudicarie fault (Fig. 1). At this longitude, we observe a sharp change in the amplitude of the high-velocity anomaly: further east, the strong, fast anomaly disappears below about $80 \mathrm{~km}$ in our surface-wave model (Fig. 3c, d, along strike section in Figure S14). Below this depth, a region of more diffuse, slightly elevated velocities (Fig. 3c) and no clear separation between eastern Alpine and Dinaric domain is observed. In addition, a separate high-velocity anomaly (EANA Figs. 2, 3c) is found more to the north beneath the European foreland at depth of about 100-150 km. Given that a subduction of the European plate affected both central and eastern Alps until at least $35 \mathrm{Ma}$ ago (e.g., Handy et al. 2015, and references therein), the reduction of anomaly strength between the two Alpine domains suggests that they must have experienced a different evolution in more recent times (Fig. 2 CAA to EAA): the European slab under the eastern Alps is either thinned, or even broken off. The high-velocity anomaly under the eastern Alps at 60-200 km depth may also correspond to the Adriatic slab, which generally shows a lower velocity anomaly strength underneath the Apennines or Dinarides in our model. The imaged anomaly strength may furthermore be influenced by the reduced station density in the eastern Alps compared to the central Alps, however, resolution tests show that this effect is small (Kästle et al. 2018). There is a small increase in anomaly strength towards the Dinarides. Under the northern Dinarides, we interpret the anomaly attaining approx. $150 \mathrm{~km}$ depth to be of Adriatic origin because of its upwards continuity with the Adriatic crust underneath the Dinarides (Figs. 2, 3d, label AD).

\section{Body-wave tomography}

A large number of detailed models based on body-wave travel times have become available in the last 15 years (Piromallo and Morelli 2003; Lippitsch et al. 2003; Spakman and Wortel 2004; Koulakov et al. 2009; Dando et al. 2011; Mitterbauer et al. 2011; Zhao et al. 2016a; Hua et al. 2017), and recently also models based on full-waveform inversions (i.e., including both body and surface waves, e.g., Zhu et al. 2015; Fichtner and Villaseñor 2015; Beller et al. 2017; Fichtner et al. 2018). For the present study, we use a selection of those models and plot them along four section traces all perpendicular to the orogen, applying the same velocity color model (Figs. 2, 3), hence allowing for an easy visual comparison. The labels on the fast anomalies in Fig. 3 show our reinterpretations of the slab provenances as discussed in the text and are not necessarily in agreement with the original interpretations of the model authors. For the sake of clarity, we select only three body-wave models for Figs. 2, 3, 4 and present all other models in the supplementary material (Figs. S2-S14). The model of Lippitsch et al. (2003) was the first one to image the Alpine slabs in cross-sections and to suggest a slab break-off under the western Alps and a polarity reversal under the eastern Alps; the model of Koulakov et al. (2009) covers much of Europe, allowing interpretations that go beyond the Alpine region; the model of Zhao et al. (2016a) is one of the most recent ones and was the first to propose vertically continuous slabs (European and Adriatic) all along the Alpine arc. These models also illustrate the differences between different data sets and methods (Table 1). The amplitudes of a given anomaly can differ significantly due to data coverage and inversion parameters. We therefore concentrate primarily on the geometries of the anomalies rather than amplitudes.

Western Alps (Fig. 3a) In the western Alps, Lippitsch et al. (2003) propose a slab break-off at lithospheric depth. Such a break-off is also visible in the model of Beller et al. (2017). However, others observe a continuous anomaly from the lithosphere to the asthenosphere (Koulakov et al. 2009; Zhu et al. 2015; Zhao et al. 2016a; Hua et al. 2017; Lyu et al. 2017). The anomaly strength right below the Moho where the potential gap is located can be significantly influenced by the crustal correction, which can be an issue due to the very shallow, high-velocity Ivrea body (Zhao et al. 2015). An insufficient correction for this structure could result in higher velocities in the uppermost mantle which might mask the proposed slab gap, however, because many authors do not publish their individual crustal model used for the 
corrections (Table 1), it is not possible to objectively discuss this potential bias. At depths greater than $150 \mathrm{~km}$, all models agree on a broad, fast anomaly (Fig. 3), which may represent the European slab. However, the central Alpine section B (Fig. 3) indicates that the Adriatic slab from the Apenninic subduction zone is extremely close to the European one and may be merged into one structure below $250 \mathrm{~km}$ (see also paragraph below). This anomaly below the Po basin in section A may therefore also represent a combination of European and Adriatic (from the Apenninic subduction) slabs.

Central Alps (Fig. 3b) All models show a continuous anomaly to at least $200 \mathrm{~km}$ depth under the central Alps which is unanimously interpreted as European slab (Piromallo and Morelli 2003; Lippitsch et al. 2003; Koulakov et al. 2009; Mitterbauer et al. 2011; Zhu et al. 2015; Zhao et al. 2016a; Hua et al. 2017). Below this depth, the anomaly strength reduces in some models (Lippitsch et al. 2003; Mitterbauer et al. 2011; Hua et al. 2017), possibly indicating a break-off. Further south, another, well-separated fast anomaly is imaged below the Apennines that links upwards with the Adriatic crust. We attribute it to the Adriatic slab (Fig. 3a). Below a depth of around $250 \mathrm{~km}$, the two anomalies from the Alps and from the Apennines merge into a single anomaly. This could be an effect of insufficient resolution and smearing, or the European slab is merged with the Apenninic slab (models of Koulakov et al. (2009) and Zhao et al. (2016a) in Fig. 3b). A merged slab would be indistinguishable from a continuous European slab to $\geq 400 \mathrm{~km}$ depth. Such a long, continuous, European slab has been proposed by Zhao et al. (2016a). Towards the east, the slab anomaly is limited in some models by a slab gap (Lippitsch et al. 2003; Koulakov et al. 2009) or a northward step of the anomaly (Fig. 2, Fig. S1-S3, Zhao et al. 2016a).

Eastern Alps (Fig. 3c, d) Underneath the eastern Alps all models show a vertical to slightly northward dipping slab (Fig. 3c, d, S10-S12, Lippitsch et al. 2003; Piromallo and Morelli 2003; Koulakov et al. 2009; Dando et al. 2011; Mitterbauer et al. 2011; Zhu et al. 2015; Fichtner and Villaseñor 2015; Zhao et al. 2016a; Hua et al. 2017). This northward dip is most clearly expressed in the model of Lippitsch et al. (2003), who image the slab down to a depth of about $250 \mathrm{~km}$ (Fig. 3D). Dando et al. (2011) indicate that the slab may be more continuous (Fig. S10-S12) and linked vertically to a deep anomaly $(>410 \mathrm{~km})$ under the Pannonian Basin. A continuation of the fast anomaly down to at least $350 \mathrm{~km}$ is also visible in the models of Koulakov et al. (2009), Mitterbauer et al. (2011), Zhao et al. (2016a) and Hua et al. (2017) (Figs. 3c, d, S10-S12). The latter shows almost no fast anomaly in the upper $200 \mathrm{~km}$, but a clear anomaly below, opposite to the model of Lippitsch et al. (2003, Fig. S12). Horizontal sections at $150 \mathrm{~km}$ (Fig. 2, S1-S3) show that the eastern Alpine anomaly is separated from the central Alpine one by a slab gap (Lippitsch et al. 2003) or a northward step, spatially coinciding with the Giudicarie fault (Mitterbauer et al. 2011; Zhao et al. 2016a).

An additional fast anomaly is present north of the Alpine Front in the model of Lippitsch et al. (2003), whose maximum strength is at approximately $150 \mathrm{~km}$ depth, similar to the EANA in the surface-wave model (Fig. 2).

At the transition between eastern Alps and Dinarides (Fig. 3d), Lippitsch et al. (2003) indicate a shallow anomaly $(\sim 100 \mathrm{~km})$ under the northern Dinarides and a deeper one $(\sim 200 \mathrm{~km})$ under the eastern Alps. These two anomalies seem to be laterally linked, indicating that the Adriatic slab from the northern Dinarides might extend into the area underneath the eastern Alps. A similar link between northern Dinaric and eastern Alpine slabs is imaged by Dando et al. (2011) and Zhu et al. (2015, Fig. S12). In the other models the connection is much weaker or not present, however, they all show a deep anomaly, located below $300 \mathrm{~km}$ and potentially detached from the lithospheric anomalies (Figs. 3D, S12 at $200 \mathrm{~km}$ distance; Piromallo and Morelli 2003; Koulakov et al. 2009; Mitterbauer et al. 2011; Zhao et al. 2016a; Hua et al. 2017). The model of Hua et al. (2017) is partially in contrast to the other models showing a low velocity anomaly at shallow depth, which may indicate that there is a zone without slab between 100 and $200 \mathrm{~km}$ depth, hence possibly showing a break-off. In the other models, such a clear low velocity zone appears only towards the eastern limit of the Alps at the border to the Pannonian basin; the location of this border varies from 13 to $15^{\circ}$ between models (Figs. 3d, S2, S12).

\section{Other constraints on plate motion and slab break-offs}

A selection of geological data used in the literature to discuss the effects of slab break-off at the surface, as well as indications of current and past plate motions, are summarized in Fig. 1. Periadriatic magmatic activity that started around $42 \mathrm{Ma}$ ago marks the onset of slab break-off that should therefore take place at around $45 \mathrm{Ma}$ (Blanckenburg and Davies 1995). In the Carpathians, the inferred propagation of the European slab break-off, starting in the west of the arc and propagating towards the east, has been correlated to the age of magmatic activity that shows a comparable progression (e.g., Nemcok et al. 1998, and references therein). The younger magmatic activity in the Pannonian basin (Fig. 1) has been related to post-20 Ma extension resulting from slab roll back, rather than slab break-off (Fodor et al. 2008). Recently, the hypothesis of the Periadriatic magmatism being related to a slab break-off has been questioned, because of ambiguities in the origin of the magmatic intrusions and the timing of emplacement of the first plutons when subduction may still have been active (Bergomi et al. 2015; Garzanti et al. 2018; Ji et al. 2019). For the current 
study, we do not take the presence or absence of magmatic activity as argument in favor or against slab break-off, as the research on the topic is not conclusive enough.

Several studies have suggested that slab break-off should result in surface uplift which influences erosion and consequently sedimentation rates (e.g., Kuhlemann 2007; Fox et al. 2015, 2016; Schlunegger and Castelltort 2016). However, erosion is influenced by several other factors, of which especially glaciation is inferred to have a major control during the last few Ma (Kuhlemann 2007; Fox et al. 2015, 2016). The results from different numerical models investigating the effect of slab break-offs on surface uplift are ambiguous as they range between zero and more than $2 \mathrm{~mm} /$ $\mathrm{yr}$ (for a review of these models and other factors influencing slab break-off see Garzanti et al. 2018). Three peaks in the sedimentation rate have been identified: at $30 \mathrm{Ma}$ along the entire Alpine arc (Kuhlemann 2007; Schlunegger and Castelltort 2016), around $18 \mathrm{Ma}$ in the eastern Alps (Kuhlemann 2007), and in exhumation around 2 Ma mostly in the western Alps (Fox et al. 2016). Hülscher et al. (2019) also find a strong change in the sedimentation pattern in the northern Alpine foreland around $19 \mathrm{Ma}$, which they propose to be explained by a visco-elastic relaxation of the European plate that caused foreland uplift. It is expected that there is a considerable delay between uplift and an increase in sedimentation or exhumation recorded in the forelands. For example, in the central Alps, Schlunegger and Castelltort (2016) infer a delay of 5-8 Ma. The relation of these signals to a slab break-off remains therefore ambiguous and we only mention the potential uplift peaks in the discussion section below, but do not take them as definite evidence.

The shortening estimates in Fig. 1 are not directly relatable to any slab break-off, but they indicate the minimum amount of subduction north and south of the Periadriatic line, which is partially relatable to European and Adriatic shortening since $35 \mathrm{Ma}$. However, upper crustal shortening, and thus the amount of subduction tend to be underestimated, because of missing records caused by erosion and subduction of crustal material. Also, sidewards escaping material, as for large parts of the eastern Alps, may reduce the shortening estimates. We assume that the amount of subduction should be equal to or greater than the shortening in the lower plate plus an unknown portion of the upper plate shortening.

The amounts of collisional shortening in the European units of the western Alps are provided by retro-deformation of balanced cross-sections (Bellahsen et al. 2014). These calculations indicate a progressive, northward increase of shortening, varying from $21 \mathrm{~km}$ in the south to $65 \mathrm{~km}$ in the north. Recent estimates (Schmid et al. 2017) are partly different, but they rely on area balancing of the reconstructed deepest parts of the European crust. Because this reconstruction of the geometries at such depth remains much more speculative than the sections closer to the surface, we only consider the data compiled in Schmid and Kissling (2000) and Bellahsen et al. (2014). In addition to shortening of the European basement and its cover, these sequences are "underthrust" below the internal zone (Penninic units) at the transition between subduction and collision. Assessing the amount of underthrusting is difficult, but based on recent orogen-scale sections (Schmid et al. 2017) it appears to be in the order of $50 \mathrm{~km}$, except in the southernmost part of the arc, where it may not have attained $30 \mathrm{~km}$. The resulting estimate of $115 \mathrm{~km}$ for the northern part of the western Alps is in agreement with the inferred shortening of $124 \mathrm{~km}$ from Schmid and Kissling (2000) and shown in Fig. 1.

The total amount of convergence since $35 \mathrm{Ma}$ in the central Alps is estimated to be in the order of $120 \mathrm{~km}$ (Schmid et al. 1996), of which about $50 \%$ is inferred to be accommodated north of the Periadriatic line $(63 \mathrm{~km}$ : Schmid et al. 1996, 30-95 km: Rosenberg et al. 2015). Recent results propose that the shortening of the European units may be significantly higher in the range of $150 \mathrm{~km}$ (Rosenberg et al. 2019).

In the eastern Alps, minimum post-collisional shortening estimates north of the Periadriatic line are in the order of $75-110 \mathrm{~km}$ across the Tauern window, decreasing to 30-40 km towards the east (Frisch et al. 1998; Rosenberg et al. 2015). For the southern Alpine units, the estimates range around $50 \mathrm{~km}$ (Schönborn 1999; Nussbaum 2000).

The shown estimates of the counter-clockwise rotation of the Adriatic plate since $20 \mathrm{Ma}$, of $5^{\circ}$ (Le Breton et al. 2017) to $20^{\circ}$ (Ustaszewski et al. 2008), with a rotation pole close to the western Alps, are based on reconstructions of the plate motion history (Handy et al. 2010; Van Hinsbergen et al. 2019). However, the plate motion history is derived from geological and seismological evidence and therefore not completely independent of the shortening estimates or tomographic models discussed above.

The current horizontal plate motion is well constrained and in good agreement between different studies (Battaglia et al. 2004; Nocquet 2012; Metois et al. 2015; Devoti et al. 2017). It shows ongoing convergence of Adria and Europe in the eastern Alps, with a convergence rate of about $2 \mathrm{~mm} /$ yr. Based on the change in both orientation and length of the GPS vectors across the Periadriatic Fault, a collisional plate boundary between Adria and Europe can be inferred somewhere in the southern Alps between the Tauern window and the southern limit of the southern Alps. There is practically no convergence between Europe and Adria in the western and most of the central Alps, anymore (Nocquet and Calais 2004).

Measurements of vertical GPS motions are subject to higher uncertainties compared to the horizontal motions. Nevertheless, they show clear uplift in the western and central Alps, with the highest values in the northern part of the 
western Alps, which correlates with the erosion rates shown in the top panel of Fig. 1 (Serpelloni et al. 2013; Nocquet et al. 2016). In the eastern Alps, the vertical motions are more variable. In general, uplift is observed in the southern part and subsidence in the northern part, resulting in a net uplift which is much lower compared to western and central Alps.

\section{Discussion}

To discuss and assess the geometry of the slabs below the Alpine chain, we present a combined plot of the surfacewave model and selected body-wave models in Fig. 4. We merge the two models in the same sections (Fig. 3) showing the surface wave model down to $150 \mathrm{~km}$ and the body-wave

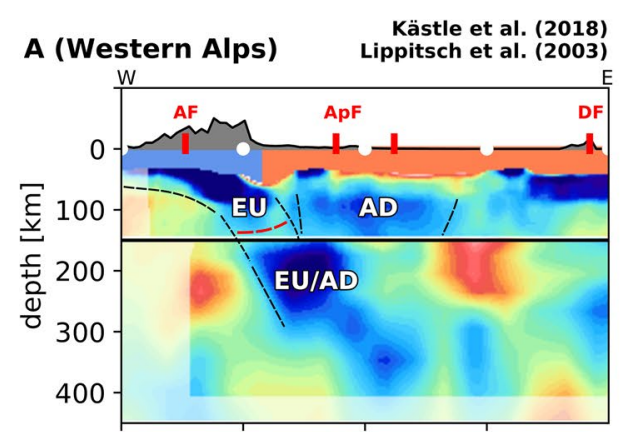

\section{B (Central Alps)}

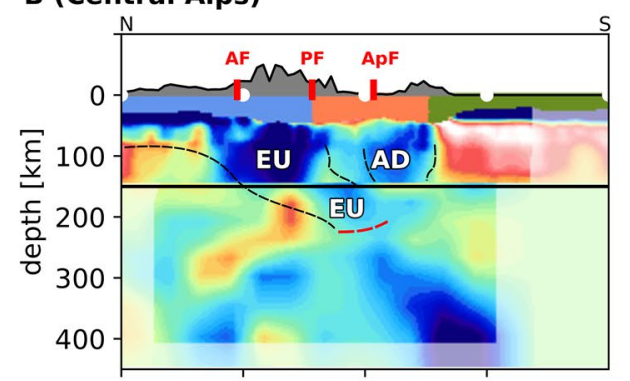

\section{C (Eastern Alps)}

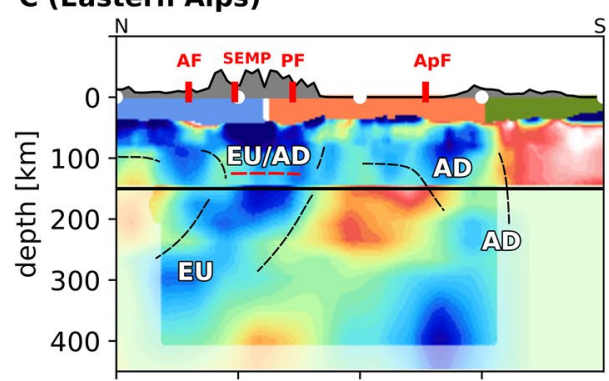

\section{D (Eastern Alps)}

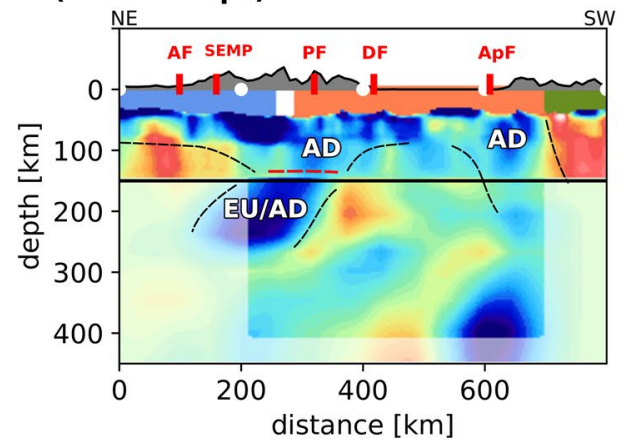

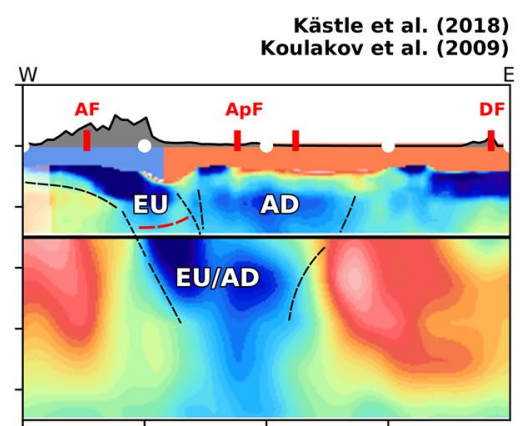
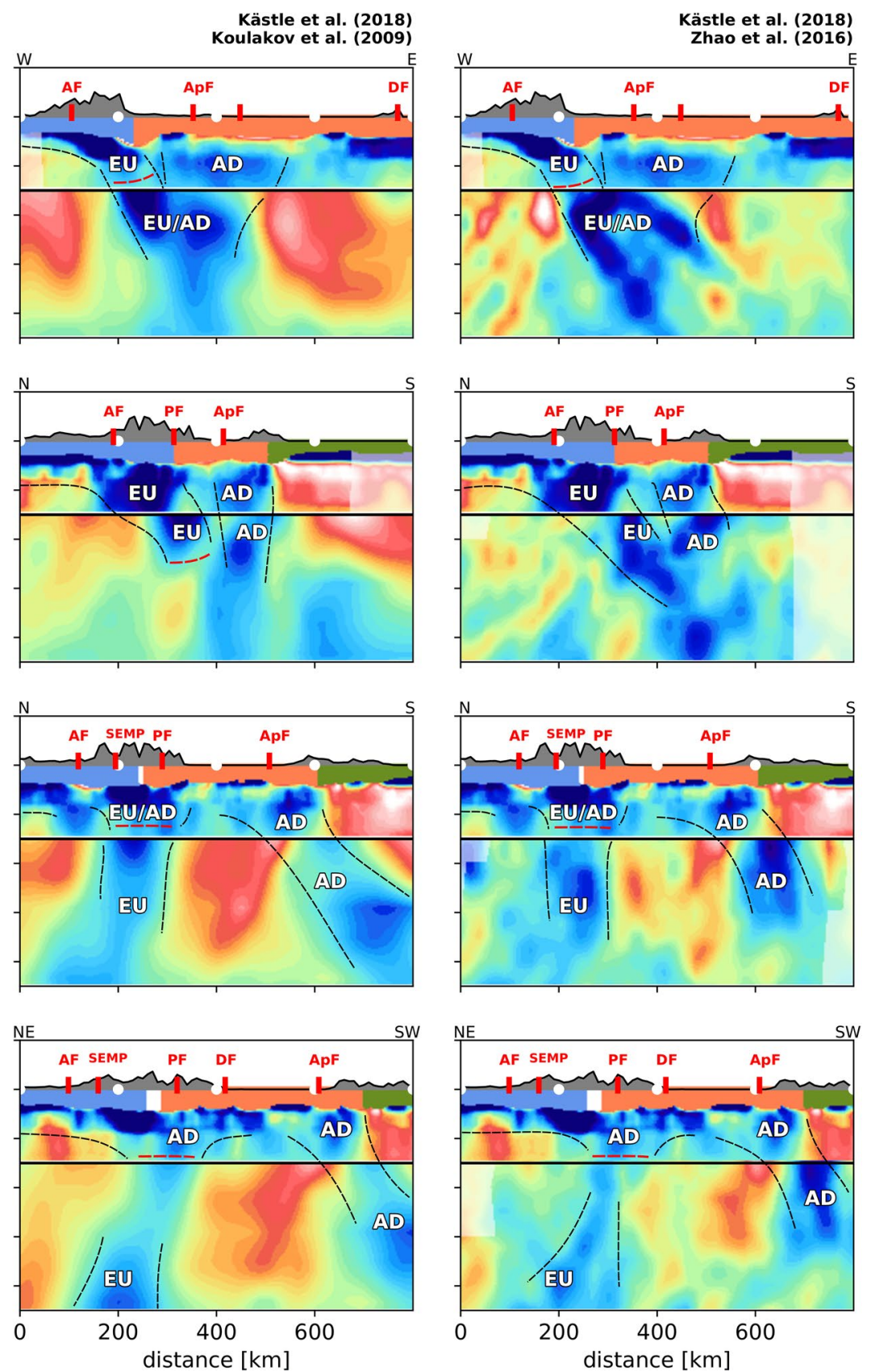

Fig. 4 Same as Fig. 3, but plotting the surface-wave model of Kästle et al. (2018) on top of the body-wave models at depths shallower than $150 \mathrm{~km}$. The mismatch in anomaly location in some places may be caused by the different methods and sensitivities of the different wave types. Black dashed lines highlight inferred slab boundaries. Red dashed lines indicate the locations of the discussed slab break-offs. See Fig. 3 for color scales and explanation of labels 
models below. The highlighted slab structures in Fig. 4 have to be interpreted with caution as the structures in both the surface- and body-wave models may be biased differently by the different ray geometries. This can cause horizontal offsets between the imaged anomalies.

\section{Western Alps}

Based on our surface-wave model (Kästle et al. 2018, Figs. 3a, 4a), the European slab under the western Alps is not as continuous as under the central Alps and may have broken off at approximately $100 \mathrm{~km}$ depth. The observed reduction in anomaly strength under the western Alps may, however, be influenced by subduction of crustal material as shown by Zhao et al. (2015). A slab break-off would agree with the models of Beller et al. (2017, full-waveform modeling) and Lippitsch et al. (2003, body-wave tomography), who locate the gap between 80 and $150 \mathrm{~km}$ depth. However, several other tomographic models image a continuous slab down to at least $250 \mathrm{~km}$ depth (Koulakov et al. 2009; Zhao et al. 2016a; Hua et al. 2017; Lyu et al. 2017), implying that there was no break-off at all in the western Alps.

Below the inferred depth of slab break-off in the western Alps, the fast anomaly can be interpreted as derived from a European slab, but an interaction with the Adriatic slab from the Apenninic subduction cannot be excluded (sec. "Bodywave tomography", Figs. 3a, 4a, label EU/AD). The shallow, attached European lithosphere and the subducted Adriatic lithosphere beneath the northern Apennines are located very close to each other and possibly in direct contact, as shown by the surface-wave model (Fig. 4a, label AD) and by the continuity of the fast anomaly from western Alps to Apennines in map view (Fig. 2, S1-S3). Lippitsch et al. (2003) and Zhao et al. (2016a) interpret this fast anomaly below $150 \mathrm{~km}$ as the European slab, dipping towards the east. However, the model of Zhao et al. (2016a) suggests that the western European Alpine slab and the Adriatic slab from the northern Apenninic subduction may be merged below $200 \mathrm{~km}$ (Fig. 3b). A distinction is difficult because of the apparent northward dip of the Apenninic slab under the northernmost part of the Apennines (Fig. 3b). Even in other models, there is no visible separation between European and Adriatic slab (Koulakov et al. 2009; Hua et al. 2017, Fig. 3). Our surface-wave model, below approx. $100 \mathrm{~km}$ depth, can only resolve a single anomaly under the Apennines that we attribute to the Adriatic slab, because of its location and continuity with the lithosphere under the Apennines (Fig. 3a).

In the context of a possible slab break-off, its timing is an important, but still open question. In the following, we discuss three scenarios: a recent (few Ma), an old (onset of continental collision) and no slab break-off.

Recent break-off The shallow slab gap imaged in several models (Lippitsch et al. 2003; Kästle et al. 2018; Beller et al.
2017) could be caused by a rather young break-off (few Ma), consistent with observations of strong exhumation and sedimentation that started around 2-7 Ma ago and is still ongoing (Fig. 1; Escher and Beaumont 1997; Kuhlemann 2007; Fox et al. 2016; Nocquet et al. 2016), although there is no measurable convergence between plates (Fig. 1). This is supported by studies showing that current uplift in the western Alps is likely not only related to deglaciation, but is also inferred to a mantle source such as slab break-off (Fox et al. 2015; Sternai et al. 2019). In addition, a recent break-off implies that the broken-off part of the European slab is still hanging in the upper mantle, as indicated by the geometry of the fast anomaly in some body-wave models between 150 and $300 \mathrm{~km}$ depth (Fig. 3a, S4-S6). The rupture could have taken place at the ocean-continent transition, assuming a considerable delay of up to $20 \mathrm{Ma}$ between collision and break-off, as shown by thermo-mechanical modeling (van Hunen and Allen 2011). Given the shortening estimates of more than $80 \mathrm{~km}$ since the onset of continental collision, the ocean-continent transition in the slab should be buried at a depth of at least $150 \mathrm{~km}$ which is at the bottom of the inferred break-off window from tomography between 80 and $150 \mathrm{~km}$. However, it is not necessary to locate the break-off to this potential weak zone at the ocean-continent transition. The slab could have weakened by thermal erosion caused by hot surrounding asthenosphere. Numerical models indicate that the interaction between slabs, as inferred for the European and Adriatic ones, can facilitate a break-off (Király et al. 2016).

Old break-off The break-off may have occurred shortly after the onset of continental collision at around $35 \mathrm{Ma}$. Invoking the same argument as for the depth of the ocean-continent transition along the slab, an assumption of $80 \mathrm{~km}$ of European collisional shortening along our section A leads to a depth of the break-off interface at $150 \mathrm{~km}$ depth or more. As this is a minimum estimate, and the shortening estimates increase significantly towards the north (Fig. 1, we infer an old break-off to be less likely, given the tomographic images of Lippitsch et al. (2003) and Kästle et al. (2018). In this scenario of a rather early (35 Ma) break-off, we assume that the broken-off part of the slab should have attained by now at least $300 \mathrm{~km}$ depth, taking low sinking velocities of $1 \mathrm{~cm} / \mathrm{a}$ into account (Capitanio et al. 2007; Replumaz et al. 2010). Contrarily to the previous scenario, this implies that the fast anomaly at about $150-300 \mathrm{~km}$ depth in cross-section A (Fig. 4, labeled EU/AD) should be of Adriatic origin from the Apenninic subduction. This contradicts several model interpretations (Lippitsch et al. 2003; Zhao et al. 2016a; Hua et al. 2017), however, the images along the western Alpine cross-sections (Fig. 4a, S4-S6) are not conclusive enough to finally discard this possibility.

No break-off A continuous slab is shown in several tomographic models (Koulakov et al. 2009; Zhao et al. 2016a; 
Hua et al. 2017; Lyu et al. 2017), however, the ray geometry in body-wave tomography tends to favor smearing along vertical rays, which may bias the results. A no break-off scenario is not in conflict with the shortening estimates and the geometry of the slab anomalies in the deeper mantle.

In summary, we consider that there is good evidence for a slab break-off from tomographic images obtained with different methods (Lippitsch et al. 2003; Kästle et al. 2018; Beller et al. 2017) which, in combination with the indications from the current uplift (Fig. 1), renders the scenario of a recent break-off the most likely one. Nevertheless, the uncertainty remains high and the no break-off scenario cannot be excluded. From a tomographic point of view, the discussion shows that next to imaging the presence or absence of a slab break-off, it is important to better understand the geometry of the deeper lying slab(s) to be able to distinguish between the different scenarios.

\section{Central Alps}

The central Alpine slab appears as a thick and subvertical anomaly in all models down to at least $200 \mathrm{~km}$ depth (Fig. 3b). The vertical termination of the slab around 200-250 km depth in most models (Piromallo and Morelli 2003; Lippitsch et al. 2003; Koulakov et al. 2009; Mitterbauer et al. 2011; Hua et al. 2017; Fichtner et al. 2018), points to a slab length of approximately $100-150 \mathrm{~km}$, closely matching interpreted amounts of convergence since $35 \mathrm{Ma}$ (Schmid et al. 1996) and the shortening estimates shown in Fig. 1. From these values, we infer that the depth of the break-off interface was at $50-100 \mathrm{~km}$ which agrees with the models of Blanckenburg and Davies (1995).

A continuous slab reaching into greater depth is only shown in the model of Zhao et al. (2016a) and possibly Zhu et al. (2015), which could imply that the slab is unbroken. However, at depths below $250 \mathrm{~km}$, the slab becomes indistinguishable from the Apenninic slab meaning that also in these models it is not necessarily Europe that is shown to be continuous (Fig. 3, S8).

This result leads to the conclusion that a break-off is likely at a depth of roughly $250 \mathrm{~km}$. The rupture would have taken place at the onset of continental collision, around $35 \mathrm{Ma}$ ago, in agreement with previous studies (Blanckenburg and Davies 1995; Lippitsch et al. 2003; Schlunegger and Castelltort 2016). The length of the still attached part of the slab can be explained with syn-collisional subduction of the European plate.

\section{Eastern Alps}

The eastern Alps are the only part of the orogen where convergence is still clearly ongoing, as shown by the GPS vectors of Fig. 1, which is linked to the counter-clockwise rotation of Adria. The classical interpretation (e.g., Hawkesworth et al. 1975; Lüschen et al. 2004) of a southdirected oceanic subduction followed by a south-directed continental subduction of Europe below Adria was questioned by Lippitsch et al. (2003), who first argued in favor of a continental subduction of Adria below Europe, in the easternmost parts of the Alps, based on the imaged $\mathrm{N}$-directed slab dip. This is also observed by other authors who interpret a continuous Adriatic slab down to at least $400 \mathrm{~km}$ depth (Zhao et al. 2016a; Hua et al. 2017). Mitterbauer et al. (2011) observe a more vertically oriented anomaly compared to the Lippitsch et al. (2003) model which they claim to be in continuity with the European Moho, hence arguing that the apparent dip direction is no reliable indication of Adriatic subduction. Dando et al. (2011) infer that the deepest part of the slab can be followed almost continuously into the deep seated highvelocity anomaly below the Pannonian Basin that they interpret as remnant of the subducted European plate. Hence the imaged slab would rather be of European origin.

To assess the likelihood of these different scenarios, we discuss below: (1) dip direction of the slab (2) continuity of the imaged slab with either the Adriatic or the European plate and Moho (3) lateral discontinuity between central and eastern Alpine slabs, (4) vertical continuity of the slab, (5) geological constraints on the amounts of collisional shortening.

1. Slab dip: the high-velocity anomalies are subvertical, with dipping angles between 70 and $90^{\circ}$ (Koulakov et al. 2009; Dando et al. 2011; Mitterbauer et al. 2011; Zhao et al. 2016a; Hua et al. 2017; Kästle et al. 2018), only Lippitsch et al. (2003) interpret the anomaly to dip with a much shallower angle of around $45^{\circ}$ to the north. The northward dip is more ambiguous, i.e., more vertical, in the western sections and more clearly visible in the eastern ones (Fig. 3, S10-S12). The resolution limit and the geometry of the ray paths may introduce artifacts that bias the apparent dipping angle. Indications for a northward dip seem nevertheless robust as they are visible in many sections through the eastern Alps (Lippitsch et al. 2003; Mitterbauer et al. 2011; Zhao et al. 2016a; Hua et al. 2017). However, along the Dinarides-Alps transition (section D in Fig. 2, analogue to the eastern Alpine section in Lippitsch et al. 2003), the apparent dip angle may be influenced by smearing between the shallow northern Dinaric anomaly and the deeper eastern Alpine one, which are not necessarily representing a single slab. Also, we suspect that section D does not cut the eastern Alpine anomaly perpendicular to its strike, but slightly oblique, which will always result in a shallower apparent angle. Indications for this are found in the $\mathrm{N}-\mathrm{S}$ oriented section in Figure S11 which shows a 
steeper dipping angle of the same slab anomaly when compared to section D (Fig. 3, S12).

2. Moho structure: attributing the high-seismic-velocity, slab-like anomaly under the eastern Alps to either the European or Adriatic plate is difficult as teleseismic body-wave tomography suffers from smearing along ray paths in the uppermost mantle and is strongly dependent on crustal velocity corrections. Additionally, the Moho structure itself suffers from uncertainty in the eastern Alps and gives no clear hint on which plate is on top (e.g., Lüschen et al. 2004; Spada et al. 2013). The most recent work along the EASI dense station profile (along $13^{\circ}$ longitude) suggests that the Adriatic Moho lies below the European one, although the uncertainty is high (Hetényi et al. 2018b) and we cannot exclude considerable along strike changes in the Moho structure. Thus, there is no reliable link between either European or Adriatic Moho and the slab anomalies below, and the surface-wave tomography does not provide any clear indications either (Fig. 3c, d, labels EU/AD).

3. Lateral continuity: the absence of a lateral continuity between central and eastern Alpine slabs is observed in all models (Lippitsch et al. 2003; Koulakov et al. 2009; Mitterbauer et al. 2011; Zhao et al. 2016a; Hua et al. 2017; Kästle et al. 2018). They show either a horizontal slab gap or a northward step of the anomaly (Fig. 2,S2S4 Lippitsch et al. 2003; Koulakov et al. 2009; Mitterbauer et al. 2011; Zhao et al. 2016a). This discontinuity approximately coincides spatially with the sinistral Giudicarie fault (e.g., Zhao et al. 2016a). In the surfacewave model, the lateral discontinuity is expressed by a decrease in anomaly strength (Fig. 2). This change of strength is similar to the one observed in the body-wave models at very shallow depth $(<150 \mathrm{~km}$, Fig. S2).

4. Vertical continuity: the eastern Alpine slab terminates sharply at $250 \mathrm{~km}$ depth in the model of Lippitsch et al. (2003, Fig. 3C,D), which, however, coincides with the boundary of the well-resolved region in their model. All other models image also deeper anomalies (Fig. 3c, d, S10-S12; Koulakov et al. 2009; Mitterbauer et al. 2011; Dando et al. 2011), possibly in continuity with the shallow slab (Zhao et al. 2016a; Hua et al. 2017). East of $14^{\circ}$ longitude, several models indicate that the shallow part of the slab disappears and only a deep slab below $250 \mathrm{~km}$ is visible (Koulakov et al. 2009; Mitterbauer et al. 2011; Zhao et al. 2016a; Hua et al. 2017, Fig. 3D). Our surface-wave model does not cover the deeper structures, but shows a weak though continuous fast anomaly in the top $200 \mathrm{~km}$ (Fig. 3c, d).

5. Shortening constraints: collisional shortening estimates for the eastern Alps are discussed above and shown in Fig. 1.
Based on the arguments above we discuss four scenarios for the eastern Alps, three of which are taken from the literature and a newly suggested fourth one, to reconcile the presented findings (Fig. 5):

\section{Scenario (I): continuous European slab down to at least $250 \mathrm{~km}$}

This scenario represents a situation analogue to the one inferred for the central Alps and was the unanimously accepted one before the work of Lippitsch et al. (2003). This scenario can explain the apparent vertical continuity of the slab, reaching to depths $\geq 350 \mathrm{~km}$ as shown in several models (Figs. 3, S10-12, Koulakov et al. 2009; Dando et al. 2011; Mitterbauer et al. 2011; Zhao et al. 2016a).

However, scenario (I) cannot explain the lateral discontinuity observed in map view (Fig. 2) and discussed above. Some models also indicate that the slab may actually not be continuous at shallow depths (Figs. 3, S10-12). The northward dip of the slab in almost all models could be used as another argument against European subduction, although it remains ambiguous because the slab could be overturned.

\section{Scenario (II): continuous Adriatic slab down to $400 \mathrm{~km}$}

Zhao et al. (2016a), Hua et al. (2017) and Hetényi et al. (2018b) propose that the vertically continuous and northward dipping fast anomaly under the eastern Alps could represent a long Adriatic slab reaching down to the mantle transition zone (Figs. 3c, d, S10-S12). This would be in

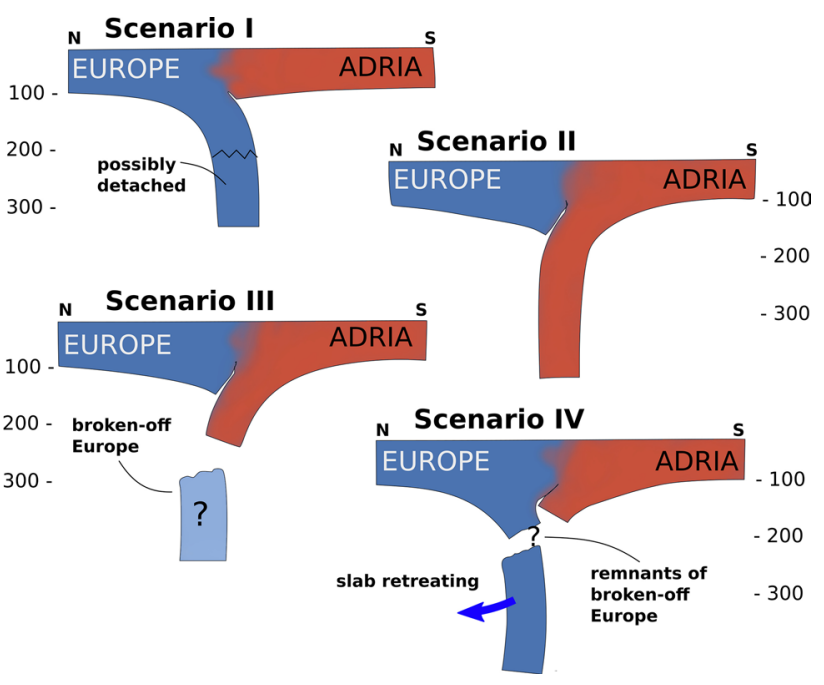

Fig. 5 Schematic illustration of four scenarios explaining the slab configuration under the eastern Alps. The section traces are located approximately along profile $\mathrm{C}$ (along $13^{\circ}$ longitude, Figs. 2). We propose that under most of the eastern Alps, Scenario IV applies, but it may approach Scenario III underneath the easternmost part 
agreement with the inferred northward directed slab dip in the shown models and a possible vertical continuity (Koulakov et al. 2009; Zhao et al. 2016a; Hua et al. 2017). This scenario is, however, in conflict with geologic evidence that is not consistent with a long-lasting Adriatic subduction in the eastern Alps (Handy et al. 2010, and references therein). Indeed, the inferred amounts of collisional shortening in the southern units of approximately $50 \mathrm{~km}$ (Fig. 1) are by far too small to explain a continuous Adriatic slab down to the mantle transition zone, even when assuming that part of the shortening has been transferred into the structures north of the Periadriatic line or has disappeared by crustal subduction or eastward extrusion.

\section{Scenario (III): Adriatic subduction down to $250 \mathrm{~km}$}

This scenario (Lippitsch et al. 2003) requires a European slab break-off and the onset of Adriatic subduction, or an extension of the Adriatic subduction from the Dinarides into the eastern Alps. Adriatic subduction would have been preceded by European slab tear which opened up the necessary space for the Adriatic slab. It has been proposed that this process may be linked to a European slab retreat toward the east, opening of the Pannonian Basin and lateral movement along the Giudicarie Fault (Schmid et al. 2004; Handy et al. 2015). This scenario can thus explain the lateral slab discontinuity from central to eastern Alps, evidenced in all tomographic models, approximately coinciding spatially with the Giudicarie Fault. It remains unclear whether such a European slab tear is related to the 32-30 Ma magmatism (Blanckenburg and Davies 1995; Rosenberg 2004) or whether a younger break-off is necessary to enable post$20 \mathrm{Ma}$ Adriatic subduction as suggested by Schmid et al. (2013). Handy et al. (2015) propose an early break-off around $35 \mathrm{Ma}$, jointly with the central Alpine one and a later one around 20-25 Ma that caused the short, remaining European slab to detach as well. A younger break-off would be supported by the inferred change in the sedimentation pattern around 19 Ma (Fig. 1, Kuhlemann 2007; Hülscher et al. 2019).

The slab length in the model of Lippitsch et al. (2003) would require 150-190 km of Adriatic shortening, which is significantly more than the observed (minimum) shortening in the southern Alps of only $50 \mathrm{~km}$ (Schönborn 1999), as inferred from balanced cross-sections (Nussbaum 2000). However, it is possible that a part of the shortening is transferred north of the Periadriatic line (Fig. 1) if the upper crust is decoupled from the subducting lithosphere or may be accommodated by lateral extrusion. The amount remains speculative and we estimate that it is unlikely that the missing $100 \mathrm{~km}$ of shortening can be explained by these mechanisms. Handy et al. (2015) propose additionally that the slab may have deformed and stretched, driven by suction from the broken-off European slab, or that the tomographic image shows an amalgamation of European and Adriatic slabs. The potentially insufficient shortening of the Adriatic crust is even more difficult to explain with respect to the other models that show a slab length of $300 \mathrm{~km}$ and more (Fig. 3, S10-S12). This suggests that at least the deeper anomalies in Fig. 3C,D (labeled EU) should be of European origin (Fig. 5 III).

\section{Scenario (IV): detached European slab, shallow subduction of Europe and Adria}

The discrepancy between minimum shortening estimates in the southern Alps and imaged slab lengths under the eastern Alps corresponds to $\geq 100 \mathrm{~km}$ for the model of Lippitsch et al. (2003) and $\geq 150 \mathrm{~km}$ for the other models. This could be caused by subduction of the European plate with a minor contribution of an Adriatic slab (Fig. 6). This has similarly been proposed by Handy et al. (2015), however, we estimate that the amount of Adriatic subduction is much lower than the previously proposed $150-190 \mathrm{~km}$ and that most
Fig. 6 3D plate configuration model of Scenario IV, where the European slab is broken off at different depth levels below the entire Alpine arc. Question marks indicate very speculative locations of the European broken-off slabs. Most of the Apenninic slab is cut out from the sketch to improve visual clarity. The structure underneath the eastern Alps is also depicted by Scenario IV in Fig. 1 with a transition to Scenario III toward the Alps-Dinarides transition

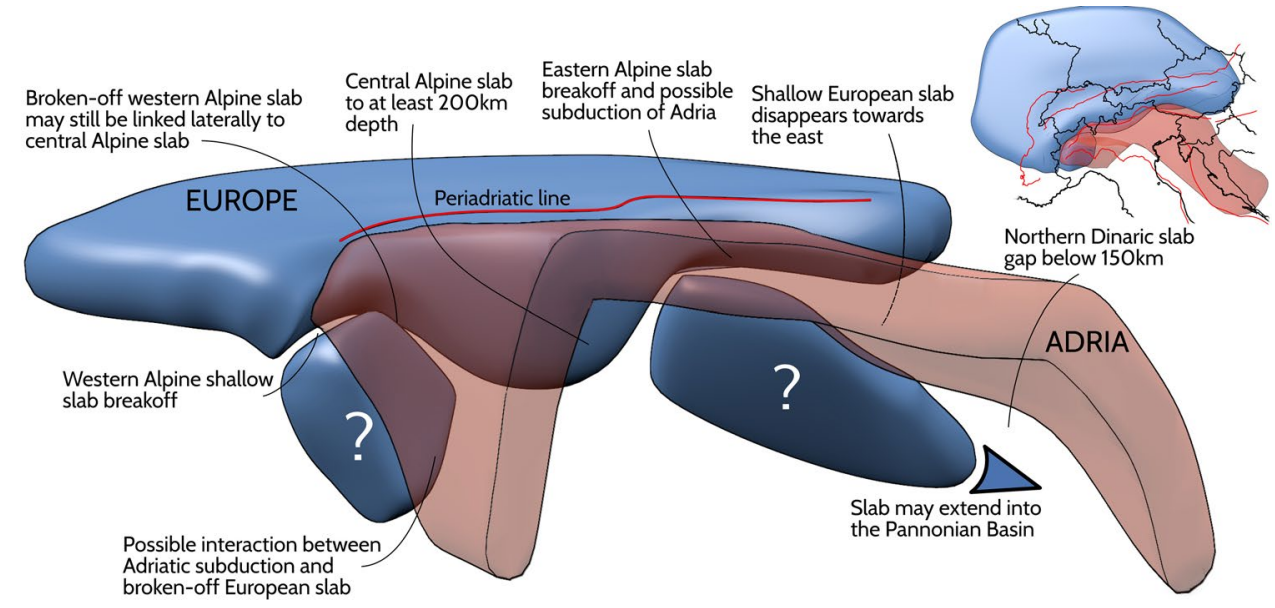


of the European slab is still present in most of the upper mantle below the eastern Alps. Considering the inferred, very shallow level of detachment of the European slab, as derived from the surface-wave model (Fig. 4) and the apparent continuity of the slab in many models, a young break-off age, significantly younger than the one inferred to cause the Periadriatic magmatism at 42-30 Ma, is required. Such a detachment could be related to the north-eastward roll back of the European slab below the Carpathians (Wortel and Spakman 2000; Schmid et al. 2004; Handy et al. 2015). This would result in a shallow slab gap similar to the one imaged by Qorbani et al. (2015) based on their SKS splitting results. This model is in agreement with the vertical slab gap in the top $250 \mathrm{~km}$, east of $15^{\circ}$ longitude (Fig. 3D, S12, Koulakov et al. 2009; Mitterbauer et al. 2011; Zhao et al. 2016a; Hua et al. 2017). A small amount of northward directed subduction of Adria filling the gap left by the broken-off European slab could explain why many tomographic models show a continuous vertical anomaly in the uppermost mantle layer between $12^{\circ}$ and $14^{\circ}$ longitude. Hence, the combination of broken-off remnants of a Europe slab and an onsetting Adriatic subduction (Fig. 5) could explain the weak, highvelocity anomaly in the surface-wave model.

A northward dip of the eastern Alpine slab is observed in most models, both in the shallow and in the deep parts of the slab. This may be caused by a retreat of the European slab (Kissling and Schlunegger 2018, proposed for the central Alps), which is being pushed by asthenospheric flow from underneath the northern Adriatic plate (e.g., Vignaroli et al. 2008), or by imaging a combination of shallow Adriatic and deep European slab (Fig. 5). A northward retreat of Europe (Handy et al. 2015) would also explain the northward step of the anomaly from central to eastern Alps as observed in some models (Zhao et al. 2016a; Hua et al. 2017). The deep, broken-off part of the European slab may furthermore be linked to the slab remnants in the mantle transition zone below the Pannonian basin (Dando et al. 2011, Fig. 6).

We assume that there is a structural transition along strike of the eastern Alps, related to the proposed breakoff: Adriatic subduction may play no or only a very minor role in the westernmost part (Tauern window, Fig. 2) where the Adriatic slab should not be significantly longer than the inferred amounts of shortening of $\sim 50 \mathrm{~km}$ (Fig. 5). Further east, the broken-off European slab is retreating and parts of the Dinaric slab may have propagated laterally, due to the counter-clockwise rotation of Adria, into the eastern Alps, thus showing a more shallowly dipping slab along section D as a combination of Adria originating in the Dinarides and retreating Europe. This approaches Scenario (III) towards the eastern end of the eastern Alps. This would explain why the northward dip is clearest at the Alps-Dinarides transition, but less obvious close to the TRANSALP cross-section along approx. 12 (Figs. 3, 6, S10-S12).

\section{Conclusions}

Our comparison of regional high-resolution tomography models shows that some of the body-wave models differ significantly in shape and length of the imaged slabs. As a consequence there is no consistent model of the Alpine subduction and slab geometries, yet. To understand detachments at lithospheric level, good resolution in the entire upper mantle up to the Moho is required. Teleseismic body-wave models are often limited in the uppermost $150 \mathrm{~km}$ due to steep incident angles of teleseismic rays, which makes it necessary to take other evidence, as from surface-wave tomography, and estimates of current and past plate motions into account.

In the western Alps, we favor the scenario of a European slab which is detached directly below the lithosphere (Lippitsch et al. 2003). A recent break-off fits best with the observations. Hence, the isostatic equilibration after slab break-off may cause the current uplift despite the absence of convergence (Fox et al. 2015). At greater depth, tomographic models cannot yet clearly distinguish between the detached European slab and Adriatic subduction under the northern Apennines that may be merged into one slab.

Concerning the eastern Alps, we object the interpretation of a continuous Adriatic slab in the entire upper mantle, however, shallow Adriatic subduction at the eastern end of the Alps cannot be ruled out. A European slab break-off could have propagated from the east, related to the eastward directed roll back of the Carpathians; Adria may have partially filled this gap (Lippitsch et al. 2003; Schmid et al. 2004; Ustaszewski et al. 2008; Handy et al. 2015). In contrast to previous works suggesting Adriatic subduction, we propose that most of the fast anomalies in the upper mantle are caused by the broken-off European slab and that Adriatic subduction plays only a minor role. We suggest that the amount of Adriatic subduction should be consistent with southern Alpine shortening estimates of $\geq 50 \mathrm{~km}$ and may only increase towards the northern Dinarides where the Adriatic slab is imaged with a length of $150 \mathrm{~km}$ (e.g., Piromallo and Morelli 2003). The northward dip of the eastern Alpine slab is therefore due to a combination of Adriatic subduction, mainly in the northern Dinarides, and a retreating, possibly overturned European slab. We summarize these findings in a new, fourth scenario, which will stimulate the discussion on the eastern Alpine slab geometries and provides a more evolved hypothesis to be further tested with the AlpArray experiment (Hetényi et al. 2018a), ideally with a combination of methods to associate the strength of both body- and surface-wave tomography.

Acknowledgements Open Access funding provided by Projekt DEAL. We are thankful to A. Paul, B. Dando, Y. Hua, I. Koulakov, U. Mitterbauer, R. Lippitsch, C. Piromallo, H. Zhu and A. Fichtner for providing the tomographic models. We want to thank M. Handy for the 
inspiring discussions on the Alpine tectonics. We are also grateful for the comments and suggestions received from S. Schmid, C. Piromallo, M. Malusà, B. Romanowicz and H. Pedersen. We acknowledge all the network operators providing data to the EIDA archive. Graphics were created with Python Matplotlib, Blender and Inkscape. EK has received funding from the French GRNE graduate school (ED-398) and the German Science Foundation (SPP-2017, Project Ha 2403/211). LB has received funding from the European Union's Horizon 2020 research and innovation program under the Marie Sklodowska-Curie grant agreement No. 641943. All data used in the surface-wave study is stored in the EIDA archive (http://www.orfeus-eu.org/eida). The surface-wave model of Kästle et al. (2018) is freely accessible, including Python routines for plotting (http://hestia.lgs.jussieu.fr/ boschil/ downloads.html). The other tomographic models are available via the original publications or from the authors upon request.

Open Access This article is licensed under a Creative Commons Attribution 4.0 International License, which permits use, sharing, adaptation, distribution and reproduction in any medium or format, as long as you give appropriate credit to the original author(s) and the source, provide a link to the Creative Commons licence, and indicate if changes were made. The images or other third party material in this article are included in the article's Creative Commons licence, unless indicated otherwise in a credit line to the material. If material is not included in the article's Creative Commons licence and your intended use is not permitted by statutory regulation or exceeds the permitted use, you will need to obtain permission directly from the copyright holder. To view a copy of this licence, visit http://creativecommons.org/licenses/by/4.0/.

\section{References}

Argnani A (2012) Plate motion and the evolution of Alpine Corsica and Northern Apennines. Tectonophysics 579:207-219

Auer L, Boschi L, Becker T, Nissen-Meyer T, Giardini D (2014) Savani: a variable resolution whole-mantle model of anisotropic shear velocity variations based on multiple data sets. J Geophys Res: Solid Earth 119(4):3006-3034

Barth S, Oberli F, Meier M (1989) UThPb systematics of morphologically characterized zircon and allanite: a high-resolution isotopic study of the Alpine Rensen pluton (northern Italy). Earth Planet Sci Lett 95(3-4):235-254

Battaglia M, Murray MH, Serpelloni E, Bürgmann R (2004) The Adriatic region: an independent microplate within the Africa-Eurasia collision zone. Geophys Res Lett 31(9):L09605

Bellahsen N, Mouthereau F, Boutoux A, Bellanger M, Lacombe O, Jolivet L, Rolland Y (2014) Collision kinematics in the western external Alps. Tectonics 33(6):1055-1088

Beller S, Monteiller V, Operto S, Nolet G, Paul A, Zhao L (2017) Lithospheric architecture of the South-Western Alps revealed by multiparameter teleseismic full-waveform inversion. Geophys $\mathbf{J}$ Int 212(2):1369-1388

Berger A, Mercolli I, Kapferer N, Fügenschuh B (2012) Single and double exhumation of fault blocks in the internal Sesia-Lanzo Zone and the Ivrea-Verbano Zone (Biella, Italy). Int J Earth Sci 101(7):1877-1894

Bergomi MA, Zanchetta S, Tunesi A (2015) The Tertiary dike magmatism in the Southern Alps: geochronological data and geodynamic significance. Int J Earth Sci 104(2):449-473

Bigioggero B, Colombo A (1994) The Oligocene Valle del Cervo pluton: an example of shoshonitic magmatism in the Western Italian Alps. Memorie die Scienze Geologiche 46(1994):409-421
Blanckenburg F, Davies JH (1995) Slab breakoff: a model for syncollisional magmatism and tectonics in the Alps. Tectonics 14(1):120-131

Bodin T, Maupin V (2008) Resolution potential of surface wave phase velocity measurements at small arrays. Geophys J Int 172(2):698-706

Boschi L, Ekström G, Kustowski B (2004) Multiple resolution surface wave tomography: the Mediterranean basin. Geophys J Int 157(1):293-304

Boschi L, Faccenna C, Becker T (2010) Mantle structure and dynamic topography in the Mediterranean Basin. Geophys Res Lett 37(20):L20303

Capitanio F, Morra G, Goes S (2007) Dynamic models of downgoing plate-buoyancy driven subduction: subduction motions and energy dissipation. Earth Planet Sci Lett 262(1-2):284-297

Carminati E, Lustrino M, Doglioni C (2012) Geodynamic evolution of the central and western mediterranean: tectonics vs. igneous petrology constraints. Tectonophysics 579:173-192

Dando B, Stuart G, Houseman G, Hegedüs E, Brückl E, Radovanović $S$ (2011) Teleseismic tomography of the mantle in the Carpathian-Pannonian region of central Europe. Geophys J Int 186(1):11-31

Del Moro A, Ferrara G, Tonarini S, Callegari E (1983) Rb-Sr systematics on rocks from the Adamello batholith (Southern Alps). Memorie della Societa Geologica Italiana 26(1):261-284

Devoti R, D’Agostino N, Serpelloni E, Pietrantonio G, Riguzzi F, Avallone A, Cavaliere A, Cheloni D, Cecere G, D'Ambrosio C et al (2017) A combined velocity field of the Mediterranean region. Ann Geophys 60(2):0215

Dewey J, Helman M, Knott S, Turco E, Hutton D (1989) Kinematics of the western Mediterranean. Geol Soc London, Special Publications 45(1):265-283

Escher A, Beaumont C (1997) Formation, burial and exhumation of basement nappes at crustal scale: a geometric model based on the Western Swiss-Italian Alps. J Struct Geol 19(7):955-974

Fichtner A, Villaseñor A (2015) Crust and upper mantle of the western Mediterranean-Constraints from full-waveform inversion. Earth Planet Sci Lett 428:52-62

Fichtner A, van Herwaarden DP, Afanasiev M, Simute S, Krischer L, Çubuk-Sabuncu Y, Taymaz T, Colli L, Saygin E, Villaseñor A et al (2018) The collaborative seismic earth model: generation 1. Geophys Res Lett 45(9):4007-4016

Fodor LI, Gerdes A, Dunkl I, Koroknai B, Pécskay Z, Trajanova M, Horváth P, Vrabec M, Jelen B, Balogh K et al (2008) Miocene emplacement and rapid cooling of the Pohorje pluton at the Alpine-Pannonian-Dinaridic junction. Slovenia. Swiss J Geosci 101(1):255-271

Fox M, Herman F, Kissling E, Willett SD (2015) Rapid exhumation in the western alps driven by slab detachment and glacial erosion. Geology 43(5):379-382

Fox M, Herman F, Willett SD, Schmid SM (2016) The exhumation history of the European Alps inferred from linear inversion of thermochronometric data. Am J Sci 316(6):505-541

Frisch W, Kuhlemann J, Dunkl I, Brügel A (1998) Palinspastic reconstruction and topographic evolution of the Eastern Alps during late Tertiary tectonic extrusion. Tectonophysics 297(1-4):1-15

Fry B, Deschamps F, Kissling E, Stehly L, Giardini D (2010) Layered azimuthal anisotropy of Rayleigh wave phase velocities in the European Alpine lithosphere inferred from ambient noise. Earth Planet Sci Lett 297(1):95-102

Garzanti E, Radeff G, Malusà MG (2018) Slab breakoff: a critical appraisal of a geological theory as applied in space and time. Earth Sci Rev 177:303-319

Handy MR, Schmid SM, Bousquet R, Kissling E, Bernoulli D (2010) Reconciling plate-tectonic reconstructions of Alpine Tethys with 
the geological-geophysical record of spreading and subduction in the Alps. Earth Sci Rev 102(3):121-158

Handy MR, Ustaszewski K, Kissling E (2015) Reconstructing the Alps-Carpathians-Dinarides as a key to understanding switches in subduction polarity, slab gaps and surface motion. Int J Earth Sci 104(1):1-26

Harangi S, Downes H, Seghedi I (2006) Tertiary-Quaternary subduction processes and related magmatism in the Alpine-Mediterranean region. Geol Soc London, Memoirs 32(1):167-190

Hawkesworth C, Waters D, Bickle M (1975) Plate tectonics in the Eastern Alps. Earth Planet Sci Lett 24(3):405-413

Hetényi G, Molinari I, Clinton J, Bokelmann G, Bondár I, Crawford WC, Dessa JX, Doubre C, Friederich W, Fuchs F et al (2018a) The AlpArray seismic network: a large-scale European experiment to image the Alpine orogen. Surv Geophys 39(5):1009-1033

Hetényi G, Plomerová J, Bianchi I, Exnerová HK, Bokelmann G, Handy MR, Babuška V, Group AEW, et al (2018b) From mountain summits to roots: Crustal structure of the Eastern Alps and Bohemian Massif along longitude 13.3E. Tectonophysics 744:239-255

Hua Y, Zhao D, Xu Y (2017) P-wave anisotropic tomography of the Alps. J Geophys Res: Solid Earth 122(6):4509-4528

Hülscher J, Fischer G, Grunert P, Auer G, Bernhardt A (2019) Selective recording of tectonic forcings in an Oligocene/Miocene submarine channel system: insights from new age constraints and sediment volumes from the Austrian Northern Alpine Foreland Basin. Frontiers in Earth Science 7:302

Ji WQ, Malusà MG, Tiepolo M, Langone A, Zhao L, Wu FY (2019) Synchronous Periadriatic magmatism in the Western and Central Alps in the absence of slab breakoff. Terra Nova 31(2):120-128

Kästle ED, Soomro R, Weemstra C, Boschi L, Meier T (2016) Tworeceiver measurements of phase velocity: cross-validation of ambient-noise and earthquake-based observations. Geophys J Int 207(3):1493-1512

Kästle ED, El-Sharkawy A, Boschi L, Meier T, Rosenberg C, Bellahsen N, Cristiano L, Weidle C (2018) Surface wave tomography of the Alps using ambient-noise and earthquake phase velocity measurements. J Geophys Res: Solid Earth 123(2):1770-1792

Király Á, Capitanio FA, Funiciello F, Faccenna C (2016) Subduction zone interaction: controls on arcuate belts. Geology 44(9):715-718

Kissling E, Schlunegger F (2018) Rollback orogeny model for the evolution of the Swiss Alps. Tectonics 37(4):1097-1115

Kissling E, Schmid SM, Lippitsch R, Ansorge J, Fügenschuh B (2006) Lithosphere structure and tectonic evolution of the Alpine arc: new evidence from high-resolution teleseismic tomography. Geol Soc London, Memoirs 32(1):129-145

Kolínsky P, Bokelmann G, AAWGroup (2019) Arrival angles of teleseismic fundamental mode Rayleigh waves across the AlpArray. Geophys J Int 218(1):114-144

Koulakov I, Kaban M, Tesauro M, Cloetingh S (2009) P-and S-velocity anomalies in the upper mantle beneath Europe from tomographic inversion of ISC data. Geophys J Int 179(1):345-366

Kuhlemann J (2007) Paleogeographic and paleotopographic evolution of the Swiss and Eastern Alps since the Oligocene. Glob Planet Change 58(1-4):224-236

Laubscher H (1971) Das Alpen-Dinariden-Problem und die Palinspastik der südlichen Tethys. Geol Rundschau 60(3):813-833

Le Breton E, Handy MR, Molli G, Ustaszewski K (2017) Post-20 Ma Motion of the Adriatic Plate: new Constraints From Surrounding Orogens and Implications for Crust-Mantle Decoupling. Tectonics 36(12):3135-3154
Lippitsch R, Kissling E, Ansorge J (2003) Upper mantle structure beneath the Alpine orogen from high-resolution teleseismic tomography. J Geophys Res: Solid Earth 108(B8)

Lu Y, Stehly L, Paul A, AAWGroup (2018) High-resolution surface wave tomography of the European crust and uppermost mantle from ambient seismic noise. Geophys J Int 214(2):1136-1150

Lüschen E, Lammerer B, Gebrande H, Millahn K, Nicolich R, TWGroup, et al. (2004) Orogenic structure of the Eastern Alps, Europe, from TRANSALP deep seismic reflection profiling. Tectonophysics 388(1):85-102

Lyu C, Pedersen HA, Paul A, Zhao L, Solarino S (2017) Shear wave velocities in the upper mantle of the Western Alps: new constraints using array analysis of seismic surface waves. Geophys J Int 210(1):321-331

Metois M, D'Agostino N, Avallone A, Chamot-Rooke N, Rabaute A, Duni L, Kuka N, Koci R, Georgiev I (2015) Insights on continental collisional processes from GPS data: dynamics of the periAdriatic belts. J Geophys Res: Solid Earth 120(12):8701-8719

Mitterbauer U, Behm M, Brückl E, Lippitsch R, Guterch A, Keller GR, Koslovskaya E, Rumpfhuber EM, Šumanovac F (2011) Shape and origin of the East-Alpine slab constrained by the ALPASS teleseismic model. Tectonophysics 510(1):195-206

Molinari I, Morelli A (2011) EPcrust: a reference crustal model for the European Plate. Geophys J Int 185(1):352-364

Molinari I, Verbeke J, Boschi L, Kissling E, Morelli A (2015) Italian and Alpine three-dimensional crustal structure imaged by ambient-noise surface-wave dispersion. Geochem Geophys 16(12):4405-4421

Molli G, Malavieille J (2011) Orogenic processes and the Corsica/ Apennines geodynamic evolution: insights from Taiwan. Int $\mathrm{J}$ Earth Sci 100(5):1207-1224

Müller W, Mancktelow NS, Meier M (2000) Rb-Sr microchrons of synkinematic mica in mylonites: an example from the DAV fault of the Eastern Alps. Earth Planet Sci Lett 180(3-4):385-397

Nemcok M, Pospisil L, Lexa J, Donelick R (1998) Tertiary subduction and slab break-off model of the Carpathian-Pannonian region. Tectonophysics 295(3-4):307-340

Nita B, Maurya S, Montagner JP (2016) Anisotropic tomography of the European lithospheric structure from surface wave studies. Geochem Geophys 17(6):2015-2033

Nocquet JM (2012) Present-day kinematics of the Mediterranean: a comprehensive overview of GPS results. Tectonophysics 579:220-242

Nocquet JM, Calais E (2004) Geodetic measurements of crustal deformation in the Western Mediterranean and Europe. Pure Appl Geophys 161(3):661-681

Nocquet JM, Sue C, Walpersdorf A, Tran T, Lenôtre N, Vernant P, Cushing M, Jouanne F, Masson F, Baize S et al (2016) Presentday uplift of the western Alps. Sci Rep 6:28404

Nussbaum C (2000) Neogene tectonics and thermal maturity of sediments of the easternmost southern Alps (Friuli area, Italy). PhD thesis

Oberli F, Meier M, Berger A, Rosenberg CL, GierÉ R (2004) U-Th$\mathrm{Pb}$ and $230 \mathrm{Th} / 238 \mathrm{U}$ disequilibrium isotope systematics: precise accessory mineral chronology and melt evolution tracing in the Alpine Bergell intrusion. Geochim Cosmochim Acta 68(11):2543-2560

Pamić J, Belak M, Bullen T, Lanphere M, McKee E (2000) Geochemistry and geodynamics of a Late Cretaceous bimodal volcanic association from the southern part of the Pannonian Basin in Slavonija (Northern Croatia). Mineral Petrol 68(4):271-296

Piromallo C, Morelli A (2003) P wave tomography of the mantle under the alpine-mediterranean area. J Geophys Res: Solid Earth 108(B2) 
Qorbani E, Bianchi I, Bokelmann G (2015) Slab detachment under the Eastern Alps seen by seismic anisotropy. Earth Planet Sci Lett 409:96-108

Replumaz A, Negredo AM, Villasenor A, Guillot S (2010) Indian continental subduction and slab break-off during Tertiary collision. Terra Nova 22(4):290-296

Romer RL, Schärer U, Steck A (1996) Alpine and pre-Alpine magmatism in the root-zone of the western Central Alps. Contrib Mineral Petrol 123(2):138-158

Rosenberg C (2004) Shear zones and magma ascent: a model based on a review of the Tertiary magmatism in the Alps. Tectonics 23(3)

Rosenberg CL, Berger A, Bellahsen N, Bousquet R (2015) Relating orogen width to shortening, erosion, and exhumation during Alpine collision. Tectonics 34(6):1306-1328

Rosenberg CL, Bellahsen N, Kästle E, Rabaute A, Boschi L (2019) Amount and distribution of collisional shortening in the Alpine Chain: implications for slab geometries at depth. Geophys Res Abs 21(EGU2019-15406)

Schivardi R, Morelli A (2009) Surface wave tomography in the European and Mediterranean region. Geophys J Int 177(3):1050-1066

Schlunegger F, Castelltort S (2016) Immediate and delayed signal of slab breakoff in Oligo/Miocene Molasse deposits from the European Alps. Sci Rep 6:31010

Schmid S, Kissling E (2000) The arc of the western alps in the light of geophysical data on deep crustal structure. Tectonics 19(1):62-85

Schmid SM, Pfiffner OA, Froitzheim N, Schönborn G, Kissling E (1996) Geophysical-geological transect and tectonic evolution of the Swiss-Italian Alps. Tectonics 15(5):1036-1064

Schmid SM, Fügenschuh B, Kissling E, Schuster R (2004) Tectonic map and overall architecture of the Alpine orogen. Eclogae Geol Helv 97(1):93-117

Schmid SM, Bernoulli D, Fügenschuh B, Matenco L, Schefer S, Schuster R, Tischler M, Ustaszewski K (2008) The Alpine-CarpathianDinaridic orogenic system: correlation and evolution of tectonic units. Swiss J Geosci 101(1):139-183

Schmid SM, Scharf A, Handy MR, Rosenberg CL (2013) The Tauern window (Eastern Alps, Austria): a new tectonic map, with crosssections and a tectonometamorphic synthesis. Swiss J Geosci 106(1):1-32

Schmid SM, Kissling E, Diehl T, van Hinsbergen DJ, Molli G (2017) Ivrea mantle wedge, arc of the Western Alps, and kinematic evolution of the Alps-Apennines orogenic system. Swiss J Geosci 110(2):581-612

Schönborn G (1999) Balancing cross sections with kinematic constraints: the Dolomites (northern Italy). Tectonics 18(3):527-545

Serpelloni E, Faccenna C, Spada G, Dong D, Williams SD (2013) Vertical GPS ground motion rates in the Euro-Mediterranean region: new evidence of velocity gradients at different spatial scales along the Nubia-Eurasia plate boundary. J Geophys Res: Solid Earth 118(11):6003-6024

Smith DB, Ritzwoller M, Shapiro N (2004) Stratification of anisotropy in the Pacific upper mantle. J Geophys Res: Solid Earth 109(B11)

Soomro R, Weidle C, Cristiano L, Lebedev S, Meier T, PWGroup et al (2016) Phase velocities of Rayleigh and Love waves in central and northern Europe from automated, broad-band, interstation measurements. Geophys J Int 204(1):517-534

Spada M, Bianchi I, Kissling E, Agostinetti NP, Wiemer S (2013) Combining controlled-source seismology and receiver function information to derive 3-D Moho topography for Italy. Geophys J Int 194(2):1050-1068
Spakman W, Wortel R (2004) A tomographic view on western Mediterranean geodynamics. The TRANSMED Atlas. The Mediterranean region from crust to mantle 31-52

Stampfli GM, Borel G (2002) A plate tectonic model for the Paleozoic and Mesozoic constrained by dynamic plate boundaries and restored synthetic oceanic isochrons. Earth Planet Sci Lett 196(1):17-33

Stehly L, Fry B, Campillo M, Shapiro N, Guilbert J, Boschi L, Giardini D (2009) Tomography of the Alpine region from observations of seismic ambient noise. Geophys J Int 178(1):338-350

Sternai P, Sue C, Husson L, Serpelloni E, Becker TW, Willett SD, Faccenna C, Di Giulio A, Spada G, Jolivet L et al (2019) Present-day uplift of the European Alps: evaluating mechanisms and models of their relative contributions. Earth Sci Rev 190:589-604

Sternai P, Sue C, Husson L, Serpelloni E, Becker TW, Willett SD, Faccenna C, Di Giulio A, Spada G, Jolivet L et al (2019) Present-day uplift of the European Alps: evaluating mechanisms and models of their relative contributions. Earth Sci Rev 190:589-604

Tesauro M, Kaban MK, Cloetingh SA (2008) EuCRUST-07: A new reference model for the European crust. Geophys Res Lett 35(5):L05313

Ustaszewski K, Schmid SM, Fügenschuh B, Tischler M, Kissling E, Spakman W (2008) A map-view restoration of the Alpine-Carpathian-Dinaridic system for the Early Miocene. Swiss J Geosci 101(1):273-294

Van Hinsbergen DJ, Torsvik TH, Schmid SM, Maţenco LC, Maffione M, Vissers RL, Gürer D, Spakman W (2019) Orogenic architecture of the Mediterranean region and kinematic reconstruction of its tectonic evolution since the Triassic. Gondwana Res (in press)

Van Hunen J, Allen MB (2011) Continental collision and slab breakoff: a comparison of 3-D numerical models with observations. Earth Planet Sci Lett 302(1-2):27-37

Verbeke J, Boschi L, Stehly L, Kissling E, Michelini A (2012) Highresolution Rayleigh-wave velocity maps of central Europe from a dense ambient-noise data set. Geophys J Int 188(3):1173-1187

Vignaroli G, Faccenna C, Jolivet L, Piromallo C, Rossetti F (2008) Subduction polarity reversal at the junction between the Western Alps and the Northern Apennines. Italy. Tectonophysics 450(1):34-50

Wortel M, Spakman W (2000) Subduction and slab detachment in the Mediterranean-Carpathian region. Science 290(5498):1910-1917

Yang Y, Ritzwoller MH, Levshin AL, Shapiro NM (2007) Ambient noise Rayleigh wave tomography across Europe. Geophys J Int 168(1):259-274

Zhao L, Paul A, Guillot S, Solarino S, Malusà MG, Zheng T, Aubert C, Salimbeni S, Dumont T, Schwartz S et al (2015) First seismic evidence for continental subduction beneath the Western Alps. Geology 43(9):815-818

Zhao L, Paul A, Malusà MG, Xu X, Zheng T, Solarino S, Guillot S, Schwartz S, Dumont T, Salimbeni S et al (2016a) Continuity of the Alpine slab unraveled by high-resolution $P$ wave tomography. J Geophys Res: Solid Earth 121(12):8720-8737

Zhao L, Paul A, Solarino S (2016b) Seismic network YP: CIFALPS temporary experiment (China-Italy-France Alps seismic transect). RESIF (Réseau Sismologique et Géodésique Français)

Zhu H, Bozdağ E, Tromp J (2015) Seismic structure of the European upper mantle based on adjoint tomography. Geophys J Int 201(1):18-52 